\title{
Glosas parentéticas en una obra historiográfica sefardí: Yildiź y sus secretos: el reino de Abdul Hamid, de Iśac Gaḅay*
}

\author{
Doğa Filiz Subaşı** \\ Universidad de Granada (España) - Universidad de Bozok (Turquía)
}

El presente trabajo se centra en el uso de las glosas parentéticas incorporadas en Yildiź y sus secretos: el reino de Abdul Hamid, una obra historiográfica escrita en aljamía hebraica en Estambul en el año 1909 por Iśac Gaḅay. En primer lugar, se organizan las glosas en tablas según su categoría gramatical, origen y forma, y en segundo lugar se pretende señalar la carencia de un uso sistemático de las glosas a lo largo de la obra. Estos análisis se acompañan de unos gráficos a fin de llegar a una conclusión estadística. Asimismo, se intenta dar respuesta al porqué del uso de las glosas.

Palabras ClaVe: Imperio otomano; glosario; léxico; judeoespañol.

Parenthetical Glosses in a Sephardic Historiographical Book. Yildiź y sus Secretos: EL REINO DE ABDUL HAMID, By IsAaC GABBAY.- This paper focuses on the use of parenthetical glosses in Yildiź y sus secretos: el reino de Abdul Hamid, a historiographical work written in Judeo-Spanish using Hebrew letters (Istanbul, 1909) by Isaac Gabbay. The glosses are first displayed in tables according to their grammatical categories, origins and forms, followed by a discussion of the lack of any systematic use of the glosses throughout the work alongside a graphical analysis. The paper also discusses the reason for the use of the glosses.

KeYwords: Ottoman Empire; Glossary; Lexicon; Judeo-Spanish.

" Queremos expresar nuestro más profundo agradecimiento a la Dra. Purificación Albarral por su inestimable ayuda a la hora de adaptar el sistema de transcripción al de la revista.

**dogafiliz@hotmail.com

Copyright: (C) 2016 CSIC. Este es un artículo de acceso abierto distribuido bajo los términos de una licencia de uso y distribución Creative Commons Attribution (CC-by) España 3.0. 


\section{INTRODUCCIÓN}

El fenómeno del uso de glosas se produce en la mayoría de la literatura sefardí a partir de mediados del siglo XIX, momento en que los autores recurren, en ocasiones, a la glosa o aclaración entre paréntesis de ciertas formas o expresiones que, a su juicio, merecen algún tipo de explicación' Sin embargo, la proporción de su uso varía según la época, la temática, la formación del autor, o la ciudad donde se redacta la obra. Incluso el origen del término glosado o de la glosa dependen de los mismos parámetros.

El judeoespañol empleado por Iśac Gabay en Yildiź y sus secretos: el reino de Abdul Hamid ${ }^{2}$ se caracteriza por la incorporación de cuantiosos

${ }^{1}$ Para las características comunes del uso de las glosas en los textos sefardíes, se pueden consultar los diferentes trabajos sobre el tema de A. García Moreno, «Glosas frescas en La hermośa Hulda de España (Jerusalén 1910)», en Los sefardíes ante los retos del mundo contemporáneo: identidad y mentalidades, eds. P. Díaz-Mas y M. SÁnchez Pérez (Madrid 2010) págs. 75-85; «Les gloses comme sources pour l'étude du lexique judéoespagnol: l'exemple de Luzero de la Pasensia (Roumania)», en Recensement, analyse et traitement numérique des sources écrits pour les études séfarades, eds. S. Rouissi y A. Stulic (Bordeaux 2013) págs. 249-271, y «Glosas de andar por casa en los cuentos sefardíes tradicionales recogidos por Cynthia Crews en Salónica a principios del siglo XX», Ladinar 7-8 (2014) págs. 95-112; así como los de B. Schmid, «La lengua sefardí en su plenitud», en Sefardies: literatura y lengua de una nación dispersa, eds. I. M. Hassán, R. IzQuierdo Benito y E. Romero (Cuenca 2008) págs. 51-79, y «"Por el adelantamiento de la nación". Las ideas lingüísticas de Abraham A. Cappon», en Los sefardíes ante los retos del mundo contemporáneo: identidad y mentalidades, eds. P. Díaz-Mas y M. Sánchez Pérez (Madrid 2010) págs. 99-112. Para un detallado análisis acerca de las diferentes funciones de las glosas en textos sefardíes véase E. HernáNDEZ Socas, C. Sinner y E. Tabares Plasencia, «La función de las glosas en El Trajumán de Michael Papo (1884)», Zeitschrift für romanische Philologie 130:2 (2014) págs. 397-429. En este trabajo atenderemos sólo al caso de Gabay en su obra.

${ }^{2}$ Se ha consultado el original en la Biblioteca de la Universidad de Harvard y comparado con el del Instituto de Yad Yizthak Ben-Zvi de Jerusalén. La obra está disponible en la página web de la Biblioteca de la Universidad de Harvard. <http://fds.lib. harvard.edu/fds/deliver/45781807/JPCDHEP2465.pdf> [consultada el 08/04/2016]. Para una información detallada sobre el libro, el autor, los capítulos y la datación de la misma, véase D. F. SubașI, «Izak Y. Gaḅay, Yildiz i sus sekretos: el reino de Abdul Hamid: descripción y datación», Miscelánea de Estudios Árabes y Hebraicos. Sección Hebreo 64 (2015) págs. 213-230; así como para las aproximaciones particulares sobre algunos capítulos véase E. Romero, La creación literaria en lengua literaria (Madrid 1992) pág. 207; «La prensa judeoespañola contra los recelos, la burocracia y la censura» en Ayer 
préstamos adaptados desde otras lenguas al fondo léxico hispánico. Una buena parte de los préstamos pertenecen a las lenguas románicas, sobre todo al francés, italiano y portugués. Tampoco faltan palabras de origen griego. Respecto a los términos hebreos, la mayoría está vinculado a la religión, aunque también se incorporan otros relacionados con la vida cotidiana. Por otra parte, no nos sorprende la aparición de palabras árabes, pues casi todas son recogidas a través del turco, una lengua llena de arabismos y persismos en la época de la redacción de la obra. No cabe duda de que la presencia de los sefardíes durante cuatro siglos en las tierras otomanas y la estrecha relación mantenida con los turcos - en Estambul en particular- originan la abundancia de préstamos turcos presentes en la lengua de Gabay; pero quizás lo más destacable sea la abundancia de los mismos en la obra en sí y en comparación con otras obras sefardíes.

En el caso concreto de la obra Yildiź y sus secretos: el reino de Abdul Hamid el estudio de las glosas adquiere una mayor importancia por ser parte de una obra dedicada a un período de la historia del Imperio Otomano y no exclusivamente a la vida sefardí; esto conlleva el uso frecuente de turquismos a lo largo de todo el texto, entendiendo que determinados conceptos no tenían su correspondencia en judeoespañol, lo que explicaría la tendencia del autor sefardí hacia los préstamos turcos. Otras veces, el autor, en vez de usar ciertos términos turcos ya conocidos por el lector, opta por sus equivalentes en lenguas románicas, glosándolos en turco. No obstante, hemos de resaltar el cuantioso uso de préstamos de origen turco que aparecen a lo largo del texto sin ser acompañados por alguna explicación o traducción integrada, ya sea ésta en forma de glosa léxica o de cualquier otra.

Por otro lado, la importancia de este trabajo de Gabay se debe también al contenido de las glosas léxicas, que comprende, en la mayoría de los casos, voces institucionales, gubernamentales o judiciales del Imperio Otomano, lo que no resulta tan frecuente en los textos sefardíes ya estudiados léxica y lexicográficamente. Por tanto, nos hallamos ante una obra que contiene en sí misma un glosario de primera mano compuesto por un autor, traductor, periodista sefardí.

y hoy de la prensa en judeoespañol, eds. P. MARtín Asuero y K. Gerson SARHON (Estambul 2007) págs. 9-36 y Entre dos (o más) fuegos: Fuentes poéticas para la historia de los sefardies de los Balcanes (Madrid 2008) págs. 301-302, 314, 315 y 390-395. 
A continuación trataremos de señalar brevemente las informaciones añadidas por el autor, ya sea en forma de notas al pie o entre paréntesis en el cuerpo del texto, antes de detenernos específicamente en el fenómeno de las glosas léxicas. Aunque no podemos considerarlas como glosa sólo por estar entre paréntesis, merecen un lugar destacado en este trabajo por tratarse de un recurso ampliamente empleado por el autor.

\section{INFORMACIONES ACLARATIVAS/ADICIONALES}

Siendo una obra historiográfica, el libro de Gaḅay ofrece datos históricos que ocupan un período de casi medio siglo. Para ayudar a mejorar el entendimiento de la obra y, también, para facilitar el recuerdo de algunos datos históricos al receptor de la obra, el autor añade informaciones, explicaciones, definiciones, aclaraciones o sinonimias a lo largo del texto, que encontramos de dos formas diferentes: 1) notas al pie, y 2) informaciones y glosas parentéticas ${ }^{3}$.

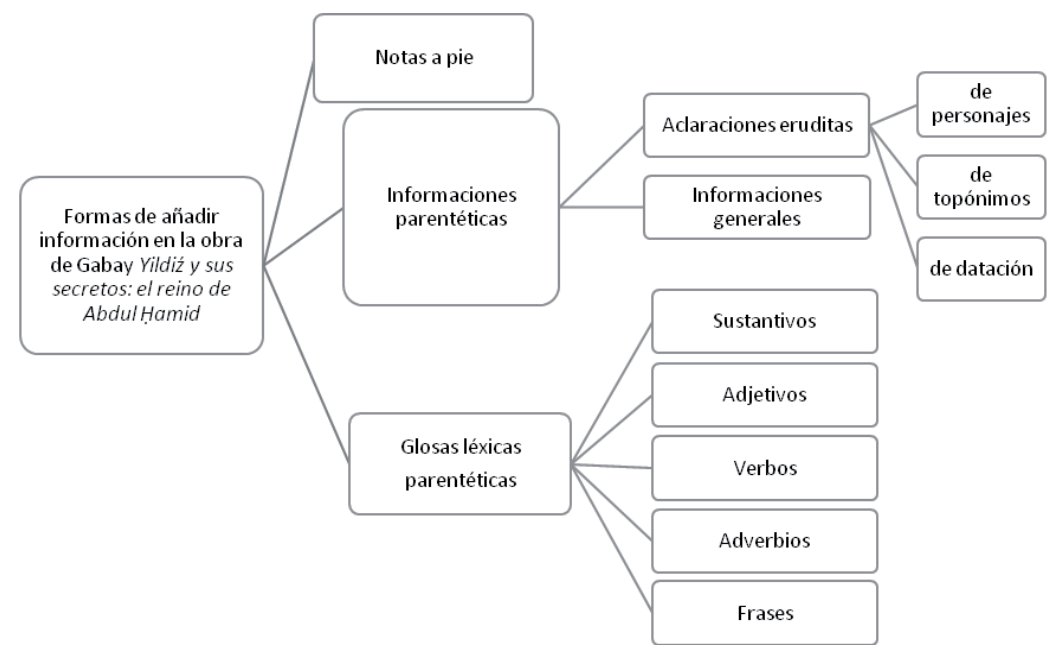

[Gráfico 1: Formas de añadir información]

${ }^{3}$ Existen otras formas de glosas no parentéticas que no son objeto de este trabajo pues merecen un estudio monográfico detallado. 


\subsection{Notas al pie}

Frente al abundante número de aclaraciones y glosas parentéticas, el recurso a las notas al pie de página es muy limitado, pues sólo las encontramos en tres ocasiones y sirven para informar a su lector sobre un personaje (nota 1) y para indicar ciertos temas que se abordarán más adelante (notas 2 y 3 ). Son:

(1) No mezclar con un otro cuñađo de Abdul Hamid que llevaba el mismo nombre Maḥmud Pačhá y que había siđo matađo en la priśión de Taíf onde había siđo mandađo en exilo (surgún [tr. sürgün ${ }^{4}$ 'exilio']) en mismo tiempo que el autor de_la primera constitución «Midḥat Pačhá» en_el año 1884. [pág. 4]

(2) Cuando algunas hojas más después trataremos de la guerra turcarusa, nuestros lectores verán en qué manera los navíos otomanos fueron destruyiđos por los rusos. [pág. 134]

(3) Hablaremos más después de_los masacros que se cometieron en Bulgaria. [pág. 182]

\subsection{Informaciones parentéticas}

Mucho más numerosas son las informaciones/aclaraciones parentéticas. Así, el texto contiene 454 usos parentéticos integrados a lo largo de sus 325 páginas (no están incluidos los que están en las últimas tres páginas, que son repetidos en el índice). La mayoría de ellos son glosas de léxico a las que prestaremos atención en detalle en el siguiente apartado. El resto de las informaciones parentéticas obedecen a diversos motivos. Algunas veces se usan para definir, aclarar o explicar algún concepto, para definir algún topónimo,

\footnotetext{
${ }^{4}$ Cabe destacar que el término sürgün se refiere en esta ocasión al 'exilio', sin embargo según el Diccionario de la Fundación de la Lengua Turca [TDK, en sus siglas en turco], consultado en versión electrónica el 8 de julio de 2016 en: http://www.tdk.gov.tr/index. php?option=com_gts\&arama=gts\&guid=TDK.GTS.577f884093e449.99348319, la palabra tiene los siguientes significados: 1- expulsado de su país, exiliado; 2- abandono de alguien de su patria, exilio; 3- lugar en que vive el exiliado, exilio (los dos últimos significados también podrían traducir como sürgünlük tal y como lo emplea Gaḅay). Adelantamos la información para evitar una posible ambigüedad acerca de la voz, dado que el autor la glosa para los tres diferentes sentidos de la palabra, cuyas equivalencias serían diferentes en el castellano.
} 
para dar información sobre personajes o para datar con exactitud. Otras veces aparecen sólo para aportar cierta información adicional o introducir la propia opinión del autor, que no define o explica la forma glosada. Probablemente se usan para dar información supuestamente de menos importancia o de importancia secundaria según el autor y de ahí que se trate de añadidos entre paréntesis. A continuación presentaremos una serie de ejemplos, agrupados en cuatro categorías: aclaraciones de topónimo, aclaraciones de personaje, y aclaraciones de datación, -entendidas todas como aclaraciones eruditas- e informaciones adicionales parentéticas ${ }^{5}$.

\subsubsection{Aclaraciones de topónimos}

Es muy común en nuestro texto que el autor recurra al uso de paréntesis para aclarar o dar información adicional sobre algún topónimo. Algunas son aclaraciones simples, y el topónimo es precisado con su sinónimo/traducción ${ }^{6}$ en otra lengua, como en:

(1) Por la una parte de este chico quiosc [tr. köşk o < fr. kiosque 'quiosco'] se topa el teatro, y por la otra el quiosc de la cascada de agua de donde se goźa de una manuífica [sic] y muy espandiđa vista sobre el Bósforo (Bogaź-ichí). [pág. 31]

Por otro lado, también se hallan aclaraciones de topónimos donde añade, el autor, información para indicar la localización de sitios (ej. 2) o para complementar sus características adicionales (ej. 3).

(2) El 23 junio, verso las horas 3 de la tarde, salió del porto de Nicópolis (sobre el Danubio) un navío quiorazađo (zirḥlí) turco con la idea de atacar, en_međio del día, a la flotilla rusa. [pág. 199]

(3) En tođas las partes de Galata y Pera (lugar donde moran los embajađores) malgrađo la rigurośa sorvelienza de los ḥafiés [tr. hafiye 'espía’] y la grande atención que haćían en las duanas, numerośos armenos recibieron armas, bombas y dinamita. [pág. 289]

\footnotetext{
${ }^{5}$ En este trabajo se ofrecen sólo algunos ejemplos de este tipo de informaciones.

${ }^{6}$ Dado que muchos términos, sobre todo topónimos y otros nombres propios en judeoespañol, se usaban indistintamente en varias lenguas, se podría considerar esta forma de glosa tanto una traducción como un sinónimo.
} 
Los ejemplos de aclaraciones toponímicas son numerosas y, en una primera aproximación, nos permite concluir que la mayoría de las veces los paréntesis explicativos son usados con la finalidad de dar el equivalente en turco del topónimo que aparece en otro idioma, sobre todo en español, por lo que podemos suponer que el turco resultaba más familiar a los lectores. Sin embargo, en algún caso encontramos el uso contrario (Ejemplo 4: Hain-Bogaź - Camino Traditor [pág. 205]), con la glosa en judeoespañol, pues se pretende además dar información extra sobre la dificultad de la ruta $\mathrm{y}$, por consiguiente, del sufrimiento de las tropas.

\subsubsection{Aclaraciones de personajes}

En la obra también encontramos numerosas aclaraciones eruditas entre paréntesis acerca de los personajes. La mayoría de las veces es una introducción de información, como sucede en los ejemplos siguientes donde el autor indica la condición de converso (ej. 5), o de buen profesional (ej. 6):

(5) Mientras que Meḥmed Alí Pačhá (inglés convertiđo al islamismo) recibió el título de generalísimo. [pág. 219]

(6) Esta socieđađ plazađa [cf. fr. placée 'situada'] bajo la preśidencia de Madam J́ośef Náar (del distinguiđo abocato), recibió una carta muy flatośa de rengraciamientos de parte del gobernador ĝeneral de Salonico. [pág. 299]

\subsubsection{Aclaraciones de datación}

A lo largo del texto nos encontramos con varias glosas utilizadas para precisar alguna información sobre la fecha o la hora, a fin de concretar algún acontecimiento (ejs. 8 y 9) o para cambiar al almanaque occidental (ejs. 10 y 11). En el sistema de datación nunca emplea o hace referencia al calendario hebreo mientras que sí lo hace al islámico, oficial, y también al cristiano. Incluso, al referirse al horario, cuando precisa una hora con el añadido «a la franca». Veamos a continuación, alguna muestra:

(7) Después de_la proclamación de_la constitución, en enero (1908) la múśica jugó en el güerto público de Tepé-baší, la marčha $[c f$. tr. marş < fr. 
marche 'marcha'] «Unión Nacional» compuesta por la princesa Hatiĝe, y que fue muy apreciađa y aplaudiđa por el púḅlico. [pág. 95]

(8) El alhađ 4 junio (día de su muerte), en la demañanađa, él quis̀o aḅajar al güerto del palacio de Chiragán onde había siđo encerrađo. [pág. 79]

(9) Taíf, 15 źilhịce ${ }^{7} 1301$ (1883). [pág. 285]

(10) Abdul Hamid era muy madrugośo. Él se levantaba en invierno a_las horas 11 , y en verano a_las 10 a_la turca (5 a_la franca). [pág. 42]

\subsubsection{Otras informaciones adicionales}

En el ejemplo 11, los paréntesis son usados por el autor para mostrar su respeto a su correligionario.

(11) Su repreśentante, el capo de_la organización, el caballero Emanuel Venećianí (de buena memoria), escojó sus escritorios en Gálata, en una grande caśa que había en un arincón y que fue más después derocađa por fraguar allí la caśa bajo la cual se topa hoy la posta alemana. [pág. 270]

En el siguiente ejemplo, hablando de la vestimenta del sultán Abdülhamit II, el autor usa los paréntesis para indicar el motivo para llevar dicha ropa, y no para describirla.

(12) Un pantalón estrecho, chaqueta de veluđo ${ }^{8}$ [pt. o gl. veludo 'terciopelo'] capladađo [cf. tr. kapla(mak) 'forrar'] por adientro con algodón (siendo él es muy friolento), y una chaqueta de paño blu-escuro [fr. bleu 'azul'] teniendo en sus bođres el šerit [tr. şerit 'fajín'] colorađo de militar, tala era, ordinariamente, su vestimienta de adientro de caśa. [pág. 55]

En el último ejemplo de este grupo, Gaḅay introduce entre paréntesis su propia opinión, al hablar sobre el presidente de la cámara otomana Ahmed Vefik Efendi:

${ }^{7}$ Duodécimo mes del calendario lunar, en el que los musulmanes suelen realizar la peregrinación a la Meca; tr. ant. zilhicce < ár. żi’l-hicce.

${ }^{8}$ La posibilidad de que estemos ante una errata de $\langle\boldsymbol{T}\rangle$ por $\langle 7>$, siendo la palabra en cuestión veluro (del fr. velours 'terciopelo') no parece tan clara si tenemos en cuenta el rafé que acompaña a nuestra dálet, que en ningún caso acompañaría a una reš. 
(13) Él [=Ahmed Vefik Efendi] es seguro que ['está seguro de que'] el Imperio Otomano no pueđe transformarse en un país constitucional (¡qué gođro yero!....). [pág. 122]

Como vemos, nos encontramos en realidad ante contenidos cuya introducción entre paréntesis en el texto es meramente coyuntural, pues bien podrían haber aparecido entre guiones de inciso, entre comas, etc. Para terminar, y como caso paradigmático de lo indiferenciado del recurrente uso de los paréntesis, tenemos el siguiente ejemplo en el que, al pie de la fotografía de uno de los más importantes bajás otomanos, se presenta entre paréntesis -claramente superfluos-, y como simple resalte tipográfico, el nombre de la ciudad donde el personaje forjó su leyenda.

\section{(14) [Fotografía]}

\section{Enver Bey}

El héroe de (Oḥrida). [pág. 309]

\section{GLOSAS DE LÉXICO}

Dejando en otro lado las aclaraciones parentéticas nos centraremos en esta contribución en las glosas parentéticas de léxico dado que la mayoría de las aclaraciones presentadas entre paréntesis en la obra son de este tipo. En el corpus nos hallamos ante ciento noventa y tres ${ }^{9}$ glosas parentéticas léxicas incorporadas en el texto: ciento cincuenta y cinco de ellas están utilizadas para aclarar un sustantivo, doce para verbos, trece para adjetivos, cuatro para adverbios, y nueve para frases completas ${ }^{10}$.

A continuación (aptdos. 3.1 a 3.5 infra), presentamos diversos listados de las glosas según la categoría gramatical de la forma glosada ${ }^{11}$. Para

\footnotetext{
${ }^{9}$ En este número no se incluyen las glosas repetidas.

${ }^{10}$ Para analizar las glosas de un texto literario sefardí nos encontramos con diferentes metodologías aplicadas por especialistas del tema; véase, por ejemplo, el ya citado trabajo de Hernández Socas et al. (vid. nota 1) en el cual también se propone un sistema de clasificación. Para la presentación las glosas seguimos la metodología usada en los trabajos de García Moreno (vid. nota 1).

${ }^{11}$ En las tablas se presentan las formas glosadas y sus glosas (sin paréntesis) transcritas a caracteres latinos. Los términos están ordenados alfabéticamente según 
establecer la tipología de las glosas, seguimos las categorías de Schmid, según las cuales «a) El neologismo se explica mediante un sinónimo aproximativo de la lengua coloquial, y b) El neologismo se explica mediante una definición, una descripción o una paráfrasis» ${ }^{12}$, si bien, a la luz de los datos de nuestro corpus, entendemos que se puede llevar a cabo una clasificación más precisa, dividiendo entre:

\section{Sinónimos [notados con $S$ en las tablas], donde tenemos:}

1.a. sinónimos totales; es decir, lo glosado se explica por su equivalente en la misma lengua o en otra. Por ejemplo, en el ej. 15, un préstamo de origen francés está explicado con una glosa de origen turco con el mismo significado:

(15) exilo (surgunluc) [pág. 118]

1.b. sinónimos aproximativos; es decir los que no tienen totalmente el mismo significado pero sí comparten un sentido aproximado. Daremos algunos ejemplos:

(16) arquitecta(s) (calfá) [págs. 29 y 40]

la forma glosada. Indicamos la procedencia de ambas formas con las siguientes abreviaturas: ár. árabe; $n g r$. griego moderno; in. inglés; es. español; $f a$. persa; $f r$. francés; $g l$. gallego; he. hebreo; it. italiano; ru. rumano; $s r$. serbio; $p t$. portugués; $t r$. turco; tr. ant. palabras antiguas turcas que están en desuso actualmente. En caso de duda del étimo de la palabra, se añaden las posibles procedencias a las que creemos que podrían pertenecer, siempre poniendo primero la que creemos que es la más cercana. En la columna Procedencia el término se presenta siempre en singular aunque aparezca en plural en el texto. Si la forma glosada o glosa corresponde al uso actual estándar de la palabra no se añade el término en la procedencia, si el significado es totalmente igual, sólo es una traducción de uno a otro idioma, tampoco se incluye. Cabe señalar que el étimo de las palabras turcas que aparecen en la tabla corresponden al turco estándar y para entender mejor su relación con el término glosado o glosa se añade el origen de la palabra tras el signo < según el Diccionario de la Fundación de la Lengua Turca (accesible en su versión digital en http://www.tdk.gov.tr/index. php?option=com_gts\&view=gts), ya que cuando se publicó la obra todavía la lengua se escribía en caracteres árabes y estaba llena de préstamos léxicos del árabe y del persa. Les sigue la columna donde se registra(n) la(s) localización(es) de los términos (página[s]: línea[s]), hasta un máximo de dos; por encima de ese número se indica el número de veces que aparece, entendiendo que no es lo mismo una glosa circunstancial que otras repetidas varias veces; hecho que justifica que nos detengamos a hacer una aproximación a su uso.

${ }^{12}$ Vid. Schmid, «La lengua sefardí en su plenitud», pág. 70. 
(17) explośar (parladear [cf. tr. parlamak 'inflamar' o patlamak 'explotar'] [pág. 75]

1.c. Añadimos también en este grupo las definiciones mediante una forma de uso metafórico.

(18) cielo (taván [tr. 'techo’]) [pág. 67]

(19) önuco [cf. fr. eunuque / es. eunuco] (arap [tr. arap 'árabe']) [pág. 99]

(20) lamentable (negro) [pág. 130]

1.d. También aquellas glosas que no corresponden a un sinónimo, sino que simplemente completan lo glosado con información adicional:

(21) en_el horiźonte (en_el cielo) [pág. 86]

(22) emigrando (viniendo) [pág. 270]

1.e. Y aquellas que muestran ejemplos de variación diafásica, contextual.

(23) ariba (nord ['norte']) [págs. 183 y186]

(24) aḅajo (sud ['sur']) [pág. 186]

\section{Explicaciones [notadas con $E$ en las tablas]:}

2.a. En cuanto a lo explicativo nos referimos a la explicación de un término, una definición o una descripción mediante paráfrasis. A veces, como vemos en el ej. 26, la formulación parafrástica funciona como forma glosada, pero en cualquier caso tanto el término glosado como la glosa pueden explicar, describir o completar al otro.

(25) abá (de lana grosieramente hecha) [pág. 127]

(26) tođos los que recibían una pensión (tacaúd) [pág. 131] 


\subsection{Glosas de sustantivos}

\begin{tabular}{|c|c|c|c|c|c|}
\hline Forma Glosada & Procedencia & Glosa & Procedencia & Tipo & Loc. \\
\hline abá & tr. ant. & $\begin{array}{c}\text { de lana } \\
\text { grosieramente } \\
\text { hecha }\end{array}$ & $\begin{array}{c}\text { es. }+c f . \text { fr. } \\
\text { grossièrement / pt. } \\
\text { grosseiramente }\end{array}$ & $\mathrm{E}$ & $127: 2-3$ \\
\hline acero & es. & chelic & tr. çelik & S & 55: 18 \\
\hline aclarađores & es. & culaguź & $\begin{array}{l}\text { tr. ant. kulağuz, } \\
\text { 'guía', 'mentor' }\end{array}$ & $\mathrm{S}$ & $247: 32$ \\
\hline aldeas & es. & quioy & tr. $k \ddot{o} y$ & $\mathrm{~S}$ & $\begin{array}{l}\text { 126: } 9 \mathrm{y} \\
185: 16\end{array}$ \\
\hline alfilares & es. 'alfileres' & alfinetes & pt. alfinetes & $\mathrm{S}$ & $23: 6$ \\
\hline almirantia & $\begin{array}{c}\text { es. } \\
\text { almirantazgo } \\
\text { 'atarazana' }\end{array}$ & tersané & $\begin{array}{l}\text { tr. tersane } \\
\text { 'atarazana' }\end{array}$ & $\mathrm{S}$ & 106: 20 \\
\hline arienda $(s)$ & es. & chiflic & tr. çiftlik & $\mathrm{S}$ & $\begin{array}{c}32: 14-5 y \\
46: 18-9\end{array}$ \\
\hline $\operatorname{arquitecta}(s)$ & es. & calfa & $\begin{array}{l}\text { tr. kalfa < ár. } \\
\text { halīfe 'ayudante de } \\
\text { arquitecto' }\end{array}$ & $\mathrm{S}$ & $\begin{array}{l}\text { 29: } 27 \mathrm{y} \\
\text { 40: } 34\end{array}$ \\
\hline atención & es. & dicat & tr. dikkat & $\mathrm{S}$ & $82: 24$ \\
\hline atentato & $\begin{array}{c}c f . \text { it. attentato / } \\
\text { fr. attentat / es. } \\
\text { atentado }\end{array}$ & $\begin{array}{l}\text { proba de } \\
\text { matarlo }\end{array}$ & $\begin{array}{l}c f . \text { it. prova / prueba } \\
+ \text { es. de matarlo }\end{array}$ & $\mathrm{E}$ & 160: 17 \\
\hline audienzas & es. audiencias & $\hat{j}$ untas & es. & $\mathrm{S}$ & 280: 17 \\
\hline aves-trućes & es. & devé-cušú & tr. devekuşu & $\mathrm{S}$ & $34: 27-8$ \\
\hline azote & es. & quirbach & tr. kırbaç & $\mathrm{S}$ & 241: 11 \\
\hline bandiera blanca & $\begin{array}{l}\text { cf. it. bandiera } \\
\text { / pt. bandeira } \\
+ \text { es. }\end{array}$ & de paz & es. & $\mathrm{E}$ & $231: 15$ \\
\hline baterías & $\begin{array}{l}c f . \text { fr. batterie / } \\
\text { es. batería }\end{array}$ & tabia & $\begin{array}{c}\text { tr. tabya < ár. ta 'biye } \\
\text { 'bastión' }\end{array}$ & $\mathrm{S}$ & $\begin{array}{l}\text { 196: } 10-1 \\
\text { y 204: } 1\end{array}$ \\
\hline bayoneta & es. & con sungyú(s) & es. + tr. süngü & $\mathrm{S}$ & 218: 4 \\
\hline bayoneta & es. & sungyú & tr. süngü & $S$ & $\begin{array}{c}79: 24 \\
\text { (+5 veces) }\end{array}$ \\
\hline bofetones & es. & šamar & tr. şamar & $\mathrm{S}$ & $68: 31$ \\
\hline
\end{tabular}




\begin{tabular}{|c|c|c|c|c|c|}
\hline Forma Glosada & Procedencia & Glosa & Procedencia & Tipo & Loc. \\
\hline bosques & es. & ormán & tr. orman & S & 211: 4 \\
\hline bučhería & $\begin{array}{l}\text { fr. boucherie } \\
\text { 'matadero' }\end{array}$ & salhané & $\begin{array}{l}\text { tr. salhane } \\
\text { 'matadero' }\end{array}$ & $\mathrm{S}$ & 244: 32 \\
\hline bufón & es. & dalcaúc & tr. dalkavuk & $\mathrm{S}$ & $\begin{array}{c}37: 7 \mathrm{y} \\
47: 2\end{array}$ \\
\hline cabina & $\begin{array}{l}\text { cf. fr. cabine / } \\
\text { es. cabina }\end{array}$ & camareta & es. & $\mathrm{S}$ & $313: 13-4$ \\
\hline caimés & tr. kayme $^{13}$ & papel moneđa & es. & $\mathrm{E}$ & $\begin{array}{c}131: 3, y \\
28-29 \\
\text { (+2 veces) }\end{array}$ \\
\hline califa & es. & capo reliǵiośo & it. + es. & $\mathrm{E}$ & 10: 27 \\
\hline calumnias & es. & iftirá & tr. iftira & $\mathrm{S}$ & $18: 27$ \\
\hline cámara & es. & $\begin{array}{l}\text { meb'usán } \\
\text { mê̂lisí }\end{array}$ & $\begin{array}{l}\text { tr. ant. mebusan } \\
\text { meclisi 'cámara } \\
\text { otomana' }\end{array}$ & $\mathrm{S}$ & 321: 17 \\
\hline camas & es. & lechos & es. & $\mathrm{S}$ & 274: 17 \\
\hline canonađa & $\begin{array}{c}c f . \text { fr. } \\
\text { canonnade } \\
\text { 'cañon' }\end{array}$ & tiros & es. (en desuso) & $\mathrm{S}$ & 186: 18 \\
\hline capitán & es. & yuź baší & tr. yüzbaşı & S & 225: 27 \\
\hline carafa & $\begin{array}{l}\text { cf. fr. carafe / } \\
\text { it. caraffa / es. } \\
\text { garrafa }\end{array}$ & surayí & tr. sürahi< ár. șurāh & $\mathrm{S}$ & $45: 23$ \\
\hline carpintero $(s)$ & es. & dogramầi & tr. doğramacl & $\mathrm{S}$ & $\begin{array}{c}39: 13 \text { y } \\
44: 15-16\end{array}$ \\
\hline cartučha(s) & $\begin{array}{l}\text { cf. fr. cartouch } \\
\text { / it. cartuccia / } \\
\text { es. cartucho }\end{array}$ & fišenc(ques) & tr. fişek < fa. fişenk & $\mathrm{S}$ & $\begin{array}{c}173: 26 \\
(+3 \text { veces })\end{array}$ \\
\hline casación & es. & temyiz & tr. ant. temyiz & $\mathrm{S}$ & 281: 11 \\
\hline caśerna & $\begin{array}{l}\text { cf. fr. caserne / } \\
\text { es. caserna }\end{array}$ & quišlá & $\begin{array}{l}\text { tr. klşla 'cuartel } \\
\text { militar' }\end{array}$ & $\mathrm{S}$ & $\begin{array}{c}279: 4 \\
(+3 \text { veces })\end{array}$ \\
\hline
\end{tabular}

${ }^{13}$ Primer papel-moneda del Imperio Otomano, que se empezó a estampar en el año 1843 durante el reino del Sultán Abdülmecit. La forma turca kayme procede del árabe kain, con el significado de 'sustituir', dado que el kayme sustituía la moneda otomana de oro o de plata; actualmente se utiliza en la lengua coloquial con el mismo valor de la forma duro en español. 


\begin{tabular}{|c|c|c|c|c|c|}
\hline Forma Glosada & Procedencia & Glosa & Procedencia & Tipo & Loc. \\
\hline caśernas & $\begin{array}{c}c f . \text { fr. caserne } e^{14} \\
\text { / es. caserna }\end{array}$ & caragoles $^{15}$ & $\begin{array}{l}\text { tr. karakol 'cuartel } \\
\text { militar' }\end{array}$ & $\mathrm{S}$ & 30: $9-10$ \\
\hline cemiterio & $\begin{array}{l}\text { cf. pt. cemitério } \\
\text { / fr. cimetière } \\
\text { / it. cimitero } \\
\text { 'cementerio' }\end{array}$ & meźarlic & tr. mezarlık & $\mathrm{S}$ & $16: 15$ \\
\hline centro & es. & en_međio & es. & $\mathrm{S}$ & 208: 3 \\
\hline $\begin{array}{c}\text { čharta } \\
\text { constitucional }\end{array}$ & $\begin{array}{l}\text { fr. charte } \\
\text { 'carta' + es. }\end{array}$ & canún esasí & tr. kanuni esasi ${ }^{16}$ & $S$ & $321: 18$ \\
\hline cielo & es. & taván & tr. tavan 'techo' & $\mathrm{S}$ & $67: 29$ \\
\hline cirugía & $\begin{array}{c}\text { cf. es. cirugía / } \\
\text { fr. chirurgie /it. } \\
\text { chirurgia }\end{array}$ & jarahlic & tr. cerrahllk & $S$ & 239: 3 \\
\hline $\begin{array}{l}\text { consejero de } \\
\text { estado }\end{array}$ & es. & $\begin{array}{l}\text { en }{ }^{17} \text { el šurayi- } \\
\text { dovlet }\end{array}$ & $\begin{array}{c}\text { tr. ant. şûrayl } \\
\text { devlet }^{18}\end{array}$ & $\mathrm{~S}$ & 4: 9 \\
\hline consilio de estado & $\begin{array}{l}\text { it. consiglio + } \\
\text { es. estado }\end{array}$ & šurayi-dovlét & tr. ant. şûrayı devlet & $S$ & $157: 32$ \\
\hline $\begin{array}{l}\text { consilio de_los } \\
\text { ministros }\end{array}$ & it. & $\begin{array}{l}\text { yuquiela- } \\
\text { meglisí }\end{array}$ & $\begin{array}{c}\text { tr. ant. meclisi } \\
\text { vükela }{ }^{19}\end{array}$ & $\mathrm{~S}$ & 138: 12 \\
\hline convento & es. & manastir & $\begin{array}{l}\text { tr. manastır } \\
\text { 'convento', } \\
\text { 'monasterio' }\end{array}$ & $S$ & 178: 6 \\
\hline cuello & es. & garón & גרון hb & $S$ & $35: 25$ \\
\hline cuevas & es. & mahżén & $\begin{array}{l}\text { tr. mahzen < ár. } \\
\text { mahzen 'almacén, } \\
\text { celda' }\end{array}$ & $\mathrm{S}$ & 291: 13 \\
\hline
\end{tabular}

${ }^{14}$ Según el Diccionario de Real Academia Española (DRAE), es voz occitana. [http:// dle.rae.es/?id=7oL7Z3H consultado el 8 de julio de 2016].

${ }^{15}$ También se podría transcribir como caragules ya que, según el diccionario etimológico online de NIŞANYAN (http://www.nisanyansozluk.com/?k=karakol\&x=0 \&y=0 [consultado el 3 de abril de 2016]), el étimo de la palabra es karagul aunque en turco actual se escribe karakol.

${ }^{16}$ Primera constitución otomana, proclamada en 1876.

${ }^{17}$ En este caso la preposición en es superflua.

${ }^{18}$ Consejo de Estado, que estuvo vigente entre 1868 y 1922.

${ }^{19}$ Consejo de ministros en el Imperio Otomano, compuesto de los ministros, şeyhülislam (título otorgado al que tenía autoridad superior en los asuntos islámicos) y sadrazam (gran visir), el cual presidía las reuniones. 


\begin{tabular}{|c|c|c|c|c|c|}
\hline Forma Glosada & Procedencia & Glosa & Procedencia & Tipo & Loc. \\
\hline $\begin{array}{l}\text { director del bureo } \\
\text { de_la prensa }\end{array}$ & es. + fr. bureau & $\begin{array}{l}\text { matbuat } \\
\text { mudurú }\end{array}$ & $\begin{array}{c}\text { tr. matbuat } \\
\text { müdürü < ár. } \\
\text { mațbū 'āt+mud̄̄r }\end{array}$ & $\mathrm{S}$ & $152: 5-6$ \\
\hline discusiones & es. & pláticas & es. & S & 138: 22 \\
\hline djornal djurnal & $\begin{array}{l}c f . \text { it. giornale, } \\
\text { tr. jurnal }\end{array}$ & raporto-secreto & $\begin{array}{l}\text { fr. rapport }+ \text { es. } \\
\text { secreto }\end{array}$ & $\mathrm{E}$ & 159: 14 \\
\hline efervecencia & es. ${ }^{20}$ & bullor & $\begin{array}{c}c f . \text { fr. bouilleur / es. } \\
\text { bullir }\end{array}$ & S & $\begin{array}{c}258: \\
13-14\end{array}$ \\
\hline emigrantes & es. & muhagigires & tr. muhacir & S & 268: $20-1$ \\
\hline enero & es. & genayo & it. gennaio & S & 246: 22 \\
\hline $\begin{array}{c}\text { enquesta } \sim \\
\text { encuesta }\end{array}$ & $\begin{array}{l}\text { cf. fr. enquête / } \\
\text { es. encuesta }\end{array}$ & tahquicat & $\begin{array}{c}\text { tr. tahkikat< ár. } \\
\text { tahkīkāt }\end{array}$ & $\mathrm{S}$ & $\begin{array}{c}50: 29 \\
(+3 \text { veces })\end{array}$ \\
\hline $\begin{array}{l}\text { eprueva(s) / } \\
\text { eprueba }(s)\end{array}$ & $\begin{array}{l}c f . \text { fr. épreuve } \\
\text { / es. prueba } \\
\text { 'experiencia' }\end{array}$ & sufrienzas & $\begin{array}{l}c f . \text { fr. souffrance } \\
\text { / it. sofferenza } \\
\text { 'sufrimiento' }\end{array}$ & S & $267: 26$ \\
\hline eqüipaĝio & $\begin{array}{c}\text { cf. it. quipaggio } \\
\text { / fr. équipage } \\
\text { / es. equipaje } \\
\text { 'tripulación' }\end{array}$ & taifá & tr. tayfa 'tripulación' & $S$ & 196: 22 \\
\hline espectáculo & es. & una vista & es. & $\mathrm{S}$ & $271: 25$ \\
\hline estađo de sedio ${ }^{21}$ & $\begin{array}{c}\text { cf. es. estado de } \\
\text { sitio / fr. état de } \\
\text { siège }\end{array}$ & idare-orfié & tr. ant. idare-i örfiye & $\mathrm{S}$ & 140: 33 \\
\hline estambulina & fr. estambulin & setré $e^{22}$ & tr. ant. setre & S & $45: 15$ \\
\hline
\end{tabular}

${ }^{20} \mathrm{El}$ termino está documentado en el Corpus Diacrónico del Español (CORDE) en 4 documentos del siglo XIX: uno en España y 3 en Hispanoamérica. [Consultado el 8 de julio 2016 en el siguiente enlace: http://corpus.rae.es/cgi-bin/crpsrvEx.dll?MfcISAPICo mmand $=$ buscar $\&$ tradQuery $=1 \&$ destino $=1 \&$ texto $=$ efervecencia\&autor $=\&$ titulo $=\&$ ano $1=$ $\&$ ano $2=\&$ medio $=1000 \&$ pais $=1000 \&$ tema $=1000]$.

${ }^{21}$ Como vulgarismo aparece en 1911 en la obra de B. Pérez Galdós, De Cartago a Sagunto (Biblioteca Virtual Miguel de Cervantes; Alicante 2002): «A mi juicio -me dijo Leonarda torciendo la boquita como hacía siempre que pronunciaba palabras escogidaspronto empezarán nuestros contrarios a zurrarnos de lo lindo, y tanto apretarán el sedio que no podrá entrar ni salir bicho viviente. Si tuviera yo mi economía en todo su pogeo, quiero decir si hubiera ajuntado dinero bastante, mañana mismo saldría de naja para Madrid». Las cursivas son del original.

${ }^{22}$ Tipo de chaqueta de cuello recto y abotonada por delante, utilizada por los turcos durante el siglo XIX. 


\begin{tabular}{|c|c|c|c|c|c|}
\hline Forma Glosada & Procedencia & Glosa & Procedencia & Tipo & Loc. \\
\hline etuvas & fr. étuve & hornos & es. & $\mathrm{S}$ & $55: 2$ \\
\hline exilađo(s) & $\begin{array}{l}c f . \text { fr. exilé / es. } \\
\text { exiliado }\end{array}$ & surgún & tr. sürgün & $\mathrm{S}$ & $\begin{array}{l}38: 5 \text { y } 18 \\
\text { y } 278: 20\end{array}$ \\
\hline exilađos & $\begin{array}{l}c f . \text { fr. exilé / es. } \\
\text { exiliado }\end{array}$ & surgunes & tr. sürgün & $\mathrm{S}$ & 135: 28 \\
\hline exilo & $\begin{array}{l}c f . \text { fr. exil / es. } \\
\text { exilio }\end{array}$ & surgún & tr. sürgün & $\mathrm{S}$ & $\begin{array}{c}20: 5-6 \\
(+4 \text { veces }) \\
\end{array}$ \\
\hline exilo & $\begin{array}{l}c f \text {. fr. exil / es. } \\
\text { exilio }\end{array}$ & surgunluc & tr. sürgünlük & $\mathrm{S}$ & 118: 24 \\
\hline explośión & es. & parladeamiento & $\begin{array}{l}c f . \text { tr. parlamak } \\
\text { 'explotar' }\end{array}$ & $\mathrm{S}$ & 197: 11 \\
\hline fetvá & $\begin{array}{l}\text { tr. fetva }<\text { ár. } \\
\qquad \text { fetv } \bar{a}^{23}\end{array}$ & ley & es. & $\mathrm{S}$ & $76: 32$ \\
\hline flaterías & fr. flatteries & hanfut & $\begin{array}{c}\text { hb. חנפות } \\
\text { 'hipocresía', doblez' }\end{array}$ & $\mathrm{S}$ & $\begin{array}{l}\text { 11: } 14 \mathrm{y} \\
117: 10\end{array}$ \\
\hline flota & es. & $\begin{array}{l}\text { navíos de } \\
\text { guerra }\end{array}$ & es. & $\mathrm{E}$ & 13: 11 \\
\hline frontiera & $\begin{array}{c}c f \text {. fr. frontière } \\
\text { / it. frontiera / } \\
\text { es. frontera }\end{array}$ & hudud & tr. hudut < ár. hudūd & $\mathrm{S}$ & $\begin{array}{c}\text { 109: } 15 \\
(+12 \\
\text { veces })\end{array}$ \\
\hline fuśil(es) & $\begin{array}{c}c f \text { fr. fusil / es. } \\
\text { fusil }\end{array}$ & tufenc & tr. tüfek $<$ fa. tufeng & $\mathrm{S}$ & $\begin{array}{c}32: 30 \\
(+5 \text { veces })\end{array}$ \\
\hline garras $^{24}$ & $\begin{array}{l}\text { cf. fr. serres / } \\
\text { it. serra / ru. } \\
\text { seră / al. serrë } \\
\text { 'invernadero' }\end{array}$ & $\begin{array}{c}\text { chichec } \\
\text { jamequianí }\end{array}$ & $\begin{array}{c}\text { tr. çiçek camekânı } \\
\text { 'invernadero de } \\
\text { flores' }\end{array}$ & $\mathrm{S}$ & $35: 28$ \\
\hline $\begin{array}{l}\text { gran maestro } \\
\text { de_la artilería }\end{array}$ & es. + fr. & $\begin{array}{l}\text { tophané } \\
\text { тиšurú }\end{array}$ & $\begin{array}{l}\text { tr. ant. tophane } \\
\text { müşiri }^{25}\end{array}$ & $\mathrm{E}$ & $\begin{array}{c}\text { 109: } 32 \text { y } \\
319: \\
12-13\end{array}$ \\
\hline $\begin{array}{l}\text { gran maestro de } \\
\text { las ceremonias }\end{array}$ & es. & tešrifatchí & tr. teşrifatçı & $\mathrm{E}$ & $\begin{array}{l}276: \\
19-20\end{array}$ \\
\hline
\end{tabular}

${ }^{23}$ Pronunciamiento legal en el islam que emite el muftí sobre una cuestión jurídica.

${ }^{24}$ Posible errata por sarras, debería decir: סארראס.

${ }^{25}$ Título otorgado a los mariscales de los cuerpos de artilleros del ejército otomano entre los años 1826 y 1908. 


\begin{tabular}{|c|c|c|c|c|c|}
\hline Forma Glosada & Procedencia & Glosa & Procedencia & Tipo & Loc. \\
\hline graveđad & es. & serieđad & es. & $\mathrm{S}$ & $53: 23$ \\
\hline haćinura de pecho & $\begin{array}{c}\text { es. } \\
\text { 'tuberculosis' }\end{array}$ & verem & tr. verem & $\mathrm{E}$ & 20: 8 \\
\hline hafielic & tr. hafiyelik & espionaje & $\begin{array}{c}\text { es. espionaje / fr. } \\
\text { espionnage }\end{array}$ & $\mathrm{S}$ & 159: 10 \\
\hline halifa & $\begin{array}{l}\text { tr. halife < ár. } \\
\text { halīfe 'califa' }\end{array}$ & capo reliĝiośo & it. + es. & $\mathrm{E}$ & 60: 15 \\
\hline hircá & $\begin{array}{l}\text { tr. hırka } \\
\text { 'chaqueta' }\end{array}$ & $\begin{array}{c}\text { especia de } \\
\text { manto ancho y } \\
\text { largo }\end{array}$ & es. & $\mathrm{E}$ & $55: 7-8$ \\
\hline hombres a pie & es. & piadé & tr. piyade 'infantería' & $\mathrm{E}$ & 224: 6 \\
\hline $\begin{array}{l}\text { hombres para } \\
\text { tiros }\end{array}$ & es. & artilería & fr. artillerie & $\mathrm{E}$ & $224: 6-7$ \\
\hline (en_el) horiźonte & es. & en_el cielo & es. & $\mathrm{S}$ & 86: 1 \\
\hline huésped(es) & es. & $\begin{array}{l}\text { misafir } ~ \\
\text { musafir }\end{array}$ & tr. misafir & $\mathrm{S}$ & $\begin{array}{l}\text { 205: } 13, \\
302: 17, y \\
307: 16\end{array}$ \\
\hline humillaciones & es. & rebajamientos & es. & $\mathrm{S}$ & $96: 5-6$ \\
\hline infantería & $\begin{array}{l}\text { cf. fr. infanterie } \\
\text { / es. infantería }\end{array}$ & piadé & tr. piyade & $\mathrm{S}$ & 297: 16 \\
\hline $\begin{array}{c}\text { instituto } \\
\text { bacteriolóǵico }\end{array}$ & es. & $\begin{array}{l}\text { por examinar } \\
\text { microbes }\end{array}$ & $\begin{array}{l}\text { es. por examinar } \\
+c f . \text { fr. microbe } \\
\text { / tr. mikrop < fr. } \\
\text { 'germen' }\end{array}$ & $\mathrm{E}$ & $54: 20-21$ \\
\hline interogatorio(s) & es. & istindac & $\begin{array}{c}\text { tr. ant. istintak< ár. } \\
\text { istințāk }\end{array}$ & $\mathrm{S}$ & $\begin{array}{c}37: 1 \\
(+4 \text { veces })\end{array}$ \\
\hline intérpreta & es. & terĝemán & $\begin{array}{c}\text { tr. tercüman < ár. } \\
\text { tercemān 'traductor, } \\
\text { trujamán' }\end{array}$ & $\mathrm{S}$ & $24: 8$ \\
\hline jaulas & es. & cafeśes & tr. kafes & $\mathrm{S}$ & $34: 25$ \\
\hline$\hat{j u n t a}(s)$ & es. & $\operatorname{seduta}(s)$ & it. seduta & $\mathrm{S}$ & $\begin{array}{l}43: 6 y \\
107: 23\end{array}$ \\
\hline laco & fr. lac 'lago' & ḩavuź & $\begin{array}{l}\text { tr. havuz 'lago', } \\
\text { 'piscina' }\end{array}$ & $\mathrm{S}$ & $\begin{array}{l}25: 1 \mathrm{y} \\
31: 22\end{array}$ \\
\hline lalás & tr. lala & $\begin{array}{l}\text { capos } \\
\text { servidores }\end{array}$ & it. + es. & $\mathrm{E}$ & $20: 32-3$ \\
\hline lápiz & es. & cará calem & $\begin{array}{l}\text { tr. karakalem 'lápiz } \\
\text { negro' }\end{array}$ & $\mathrm{S}$ & $44: 27-8$ \\
\hline
\end{tabular}




\begin{tabular}{|c|c|c|c|c|c|}
\hline Forma Glosada & Procedencia & Glosa & Procedencia & Tipo & Loc. \\
\hline lucha & es. & combate & es. & $\mathrm{S}$ & $\begin{array}{c}103: 7-8 \text { y } \\
156: 6\end{array}$ \\
\hline masacros & $\begin{array}{c}c f . \text { it. massacro } \\
\text { / es. masacre }\end{array}$ & matanzas & es. & $\mathrm{S}$ & $136: 3-4$ \\
\hline matbuat-mudirietí & $\begin{array}{l}\text { tr. matbuat } \\
\text { müdüriyeti }^{26}\end{array}$ & $\begin{array}{c}\text { bureo de_la } \\
\text { prensa }\end{array}$ & fr. + es. & $\mathrm{S}$ & 53: 20 \\
\hline méđicos quirurgos & es. & jarahes & $\begin{array}{c}\text { tr. cerrah < ár. } \\
\text { carrāh }\end{array}$ & S & $271: 16$ \\
\hline mučh(es) & $\begin{array}{l}\text { fr. bateau- } \\
\text { mouche 'barco } \\
\text { ligero' }\end{array}$ & istimbot & $\begin{array}{c}\text { tr. istimbot }<\text { in. } \\
\text { steamboat 'barco de } \\
\text { vapor' }\end{array}$ & $\mathrm{S}$ & $\begin{array}{l}31: 26 y \\
313: 29\end{array}$ \\
\hline mueles & es. & rihtim & tr. rlhtım 'muelle' & $\mathrm{S}$ & $\begin{array}{l}\text { 66: } 11 \mathrm{y} \\
272: 19\end{array}$ \\
\hline niebla & es. & dumán & $\begin{array}{l}\text { tr. duman 'humo, } \\
\text { 'niebla' }\end{array}$ & $\mathrm{S}$ & 236: 1 \\
\hline ocaśión & es. & quielepur & tr. kelepir 'ganga' & $\mathrm{S}$ & $\begin{array}{c}128: \\
26-27 \\
\end{array}$ \\
\hline odagi $i$ & tr. odacl & serviđor & es. & $\mathrm{S}$ & 291: 10 \\
\hline ӧписо & $\begin{array}{c}\text { cf. fr. еипиque / } \\
\text { es. еиписо }\end{array}$ & arap & tr. arap 'árabe' & $\mathrm{S}$ & 99: 15 \\
\hline ӧпиqие(s) / ӧписо & $\begin{array}{l}c f . \text { fr. еипиquе / } \\
\text { es. еиписо }\end{array}$ & $\begin{array}{l}\text { hadim(es)/ } \\
\text { hadum }\end{array}$ & tr. hadım & $\mathrm{S}$ & $\begin{array}{c}20: 31 \\
(+11 \\
\text { veces })\end{array}$ \\
\hline pahuela & es. pajuela & quiebrit & tr. kibrit 'cerilla' & $\mathrm{S}$ & 59: 13 \\
\hline $\begin{array}{c}\text { palo gođro } y \\
\text { corto }\end{array}$ & es. & sopa & tr. sopa & $\mathrm{E}$ & 291: 8-9 \\
\hline pañuelo(s) & es. & ridá $(s)$ & tr. ant. rida < ár. rida & $\mathrm{S}$ & $\begin{array}{l}58: 28, \\
82: 15 \mathrm{y} \\
237: 27\end{array}$ \\
\hline perquiśsición & es. en desuso & basquín & tr. baskın 'redada' & $\mathrm{S}$ & 163: 5 \\
\hline реsсиеzo & es. & garón & hb. גרון 'cuello' & $\mathrm{S}$ & $55: 14$ \\
\hline pintura & es. & resim & $\begin{array}{c}\text { tr. resim 'cuadro, } \\
\text { pintura' }\end{array}$ & $\mathrm{S}$ & 44: 13 \\
\hline $\operatorname{piso}(s)$ & es. & tabacá(s) & $\begin{array}{c}\text { tr. tabaka< ár. } \\
\text { tabaka }\end{array}$ & $\mathrm{S}$ & $\begin{array}{l}32: 2 y \\
84: 26\end{array}$ \\
\hline pomolo & $\begin{array}{c}\text { cf. it. pomello / } \\
\text { es. pomo }\end{array}$ & cadenađo & es. desuso 'candado' & $\mathrm{S}$ & 59: 6 \\
\hline ponte de pierda & $\begin{array}{l}\text { it. y pt. ponte }+ \\
\text { es. de piedra }\end{array}$ & quiuprí & tr. köprü 'puente' & $\mathrm{E}$ & 28: 12 \\
\hline
\end{tabular}

${ }^{26}$ El Matbuat Müdüriyetí fue el directorio responsable de la prensa en el Imperio Otomano. 


\begin{tabular}{|c|c|c|c|c|c|}
\hline Forma Glosada & Procedencia & Glosa & Procedencia & Tipo & Loc. \\
\hline pontes & it. y pt. ponte & quiuprís & tr. köprü 'puente' & $\mathrm{S}$ & 201: 22 \\
\hline pretes & $\begin{array}{l}\text { it. prete } \\
\text { 'sacerdote' }\end{array}$ & papaśes & $\begin{array}{l}\text { tr. papaz < ngr. } \\
\text { papás 'sacerdote' }\end{array}$ & $\mathrm{S}$ & 266: 7 \\
\hline primer-ministro & es. & $\begin{array}{c}\text { gran viśir } \\
\text { veśir }\end{array}$ & $\begin{array}{c}\text { es. gran }+c f \text {. es visir } \\
\text { / tr. vezir }\end{array}$ & $\mathrm{S}$ & $35: 6$ \\
\hline proceso & es. & daavá & $\begin{array}{l}\text { tr. dava < ár. da } a^{\varsigma} v \bar{a} \\
\text { 'proceso judicial' }\end{array}$ & $\mathrm{S}$ & $\begin{array}{l}\text { 78: } 18 \mathrm{y} \\
152: 1\end{array}$ \\
\hline procurador & es. & muda 'i- 'uтиті́ & $\begin{array}{c}\text { tr. ant. müddeiumumi } \\
<\text { ár. mudde }{ }^{\varsigma} \bar{\imath}+ \\
{ }^{\complement} u m \bar{u} m \bar{\imath}\end{array}$ & $\mathrm{S}$ & 84: 11 \\
\hline quiurazađos & $\begin{array}{c}\text { cf. fr. cuirasse } \\
+ \text { es. -ado / es. } \\
\text { acorazado }\end{array}$ & źirhlí & tr. zırhll 'acorazado' & $\mathrm{S}$ & 198: 1 \\
\hline reǵeneración & es. & revivimiento & es. & $\mathrm{S}$ & 2: 21 \\
\hline relación & es. & cuento-rendiđo & $\begin{array}{l}\text { calco del fr. compte- } \\
\text { rendu }\end{array}$ & $\mathrm{S}$ & 108: 4 \\
\hline relojería & es. & saadgilic & tr. saatçilik & $\mathrm{S}$ & 44: 12 \\
\hline repulsión & es. & aborición & $\begin{array}{c}\text { es. 'aborrecimiento, } \\
\text { odio' }\end{array}$ & $\mathrm{S}$ & 21: 7 \\
\hline rutbé & $\begin{array}{l}\text { tr. rütbe } \\
\text { 'grado' }\end{array}$ & građo & es. & $\mathrm{S}$ & 151: 2 \\
\hline (las) santinelas & $\begin{array}{l}\quad c f . \text { fr. } \\
\text { sentinelle }(s) / \\
\text { it. sentinella / } \\
\text { es. centinela }{ }^{27}\end{array}$ & noctá & tr. nokta < ár. nukța & $\mathrm{S}$ & 289: 24 \\
\hline $\begin{array}{l}\text { sentinella / } \\
\text { centinella }\end{array}$ & $\begin{array}{l}c f . \text { fr. sentinelle } \\
\text { / it. sentinella } \\
\text { 'centinela' }\end{array}$ & noctá & tr. nokta < ár. nukța & $\mathrm{S}$ & $\begin{array}{c}79: 23 y \\
98: 12-13\end{array}$ \\
\hline señas de paralisia & es. + fr. & $\begin{array}{c}\text { mancanza de } \\
\text { vida }\end{array}$ & it. + es. & $\mathrm{E}$ & $72: 2$ \\
\hline serasquier & $\begin{array}{c}\text { tr. serasker } \\
\text { [tr. serasker } \\
\text { \{fa. ser } \\
\text { 'cabeza'+ } \\
\text { tr. asker } \\
\text { 'soldado'\} 'jefe } \\
\text { del ejército'] }\end{array}$ & $\begin{array}{l}\text { ministro de la } \\
\text { guerra }\end{array}$ & es. & $\mathrm{E}$ & $\begin{array}{c}312: \\
32-33\end{array}$ \\
\hline
\end{tabular}

${ }^{27}$ Aun teniendo ciertas dudas sobre el étimo de la palabra -pues podría haberse deformado sobre la base del español estándar del momento-, nos inclinamos a pensar que la palabra proviene del francés, cuyo género femenino conserva. 


\begin{tabular}{|c|c|c|c|c|c|}
\hline Forma Glosada & Procedencia & Glosa & Procedencia & Tipo & Loc. \\
\hline šer'í & $\begin{array}{l}\text { tr. şeri< ár. } \\
\operatorname{şer}^{\varsigma} \bar{l} \text { 'sharía' }\end{array}$ & leis reliĝiośas & es. & $\mathrm{E}$ & 117: 15 \\
\hline silaḩšores & $\begin{array}{l}\text { tr. silahşör } \\
\text { 'guerreros' }\end{array}$ & $\begin{array}{l}\text { guardia } \\
\text { albaneśa }\end{array}$ & es. & $\mathrm{E}$ & $31: 2-3$ \\
\hline síntomos & it. sintomo & señas & es. & $\mathrm{S}$ & $27: 9$ \\
\hline sofá ${ }^{28}$ & $\begin{array}{l}c f . \text { fr. sofa }<\text { fa. } \\
\text { soffe / es. sofá }\end{array}$ & minder & tr. minder ${ }^{29}$ & $\mathrm{~S}$ & $80: 5$ \\
\hline softás & $\begin{array}{l}\text { tr. ant. softa }< \\
\text { fa. sūhte }\end{array}$ & hojâá(s) & tr. hoca $<$ fa. hvoāce & $\mathrm{S}$ & $\begin{array}{c}\text { 130: } 12 \mathrm{y} \\
181: 3\end{array}$ \\
\hline solevantađa & $\begin{array}{c}\text { cf. fr. } \\
\text { soulèvement / } \\
\text { it. sollevamento }\end{array}$ & revolución & es. & $\mathrm{S}$ & 205: 2 \\
\hline (de_la) superficía & $\begin{array}{c}c f . \text { fr. superficie } \\
+ \text { es. }\end{array}$ & de enriba & es. de arriba & $\mathrm{S}$ & $83: 7$ \\
\hline telales & $\begin{array}{c}\text { tr. tellal< } \\
\text { ár. dellāl } \\
\text { 'pregonero' }\end{array}$ & $\begin{array}{l}\text { gritađores } \\
\text { públicos }\end{array}$ & es. & $\mathrm{E}$ & $76: 3$ \\
\hline tiendas & es. & chadir & tr. çadır & $\mathrm{S}$ & $30: 26$ \\
\hline tintoría & es. & boyá & $\begin{array}{l}\text { tr. boya 'tinte', } \\
\text { 'pintura' }\end{array}$ & $\mathrm{S}$ & 102: 2 \\
\hline tirađor & es. & išaretchí & tr. işaretçi & $\mathrm{S}$ & $44: 3$ \\
\hline $\begin{array}{l}\text { tođos los que } \\
\text { recibían una } \\
\text { pensión }\end{array}$ & es. & tacaúd & $\begin{array}{l}\text { tr. ant. tekaüt< ár. } \\
\text { tekā 'ud 'jubilado' }\end{array}$ & $\mathrm{E}$ & $131: 25$ \\
\hline tratamiento & es. & $\begin{array}{l}\text { manera de } \\
\text { curación }\end{array}$ & es. & $\mathrm{E}$ & $88: 5$ \\
\hline tsigana & $\begin{array}{l}\text { fr. tsigane } \\
\text { 'gitano' }\end{array}$ & chingané & $\begin{array}{l}\text { tr. çingen, çingene < } \\
\text { fa. çingāna 'gitano' }\end{array}$ & $\mathrm{S}$ & 54: 15 \\
\hline turbán & $\begin{array}{l}\text { tr. } \text { türban }^{31}<\mathrm{fr} . \\
\text { turban }\end{array}$ & saric & $\begin{array}{l}\text { tr. sarlk 'tocado } \\
\text { masculino' }\end{array}$ & $\mathrm{S}$ & 135: 6 \\
\hline
\end{tabular}

${ }^{28}$ Aunque en turco también existe la palabra sofa de origen árabe șuffe, no creemos que aquí viniese del dicho idioma porque el sentido de la palabra en turco es 'vestíbulo'.

${ }^{29}$ Tipo de cojín grande (o almohadón) para sentarse, apoyarse y recostarse.

${ }^{30}$ Estudiante de madraza, teología del islam. También se utiliza para despreciar a los que están relacionados con la teología islámica.

${ }^{31}$ Palabra de origen francés utilizada en aquel entonces para un tipo de tocado de hombres, sarı. Hoy en día se utiliza para referirse al pañuelo envuelto firmemente alrededor de la cabeza, turbante $<$ tr. türban $<$ fr. turban. 


\begin{tabular}{|c|c|c|c|c|c|}
\hline Forma Glosada & Procedencia & Glosa & Procedencia & Tipo & Loc. \\
\hline turbé & $\begin{array}{c}\text { tr. türbe < ár. } \\
\text { turbe }\end{array}$ & cueva & es. 'mausoleo' & $\mathrm{S}$ & $16: 1$ \\
\hline ulemás & $\begin{array}{c}\text { tr. ant. ulema < } \\
\text { ár. 'ulemā }\end{array}$ & ḩojas & tr. hoca ${ }^{32}$ & $\mathrm{~S}$ & $\begin{array}{c}\text { 304: } \\
\text { 29-30 } \\
\text { y 307: } 14\end{array}$ \\
\hline 'ulemas & $\begin{array}{l}\text { tr. ant. ulema } \\
\text { [tr. ant. ulema } \\
\text { < ár. '́ulamā, } \\
\text { pl. de 'álim] } \\
\text { 'sabios de la } \\
\text { ley islámica' }\end{array}$ & $\begin{array}{l}\text { religiosiosos } \\
\text { otomanos }\end{array}$ & es. & $\mathrm{E}$ & 110: 22 \\
\hline uvraǵes & $\begin{array}{c}\text { fr. ouvrage } \\
\text { 'obra' }\end{array}$ & libros & es. & $\mathrm{S}$ & $3: 6$ \\
\hline $\operatorname{vali}(s)$ & $\begin{array}{c}\text { tr. vali< ár. } \\
\text { vālī }\end{array}$ & $\begin{array}{c}\text { gobernađores } \\
\text { generales }\end{array}$ & es. & $\mathrm{E}$ & 114: 27 \\
\hline vexaciones & $\begin{array}{c}c f . \text { es. } \\
\text { vejaciones / fr. } \\
\text { vexations }\end{array}$ & $\begin{array}{l}\text { feriđas de } \\
\text { amor-propia }\end{array}$ & es. & $\mathrm{E}$ & 163: 8 \\
\hline vice-amiral & $\begin{array}{c}\text { fr. amiral } \\
\text { 'almirante' } \\
\text { 'vicealmirante' }\end{array}$ & feric & $\begin{array}{c}\text { tr. ant. ferik< ár. } \\
\text { ferīk }\end{array}$ & S & 295: 24 \\
\hline viḍuy & $\begin{array}{l}\text { hb. viḍuy } \\
\text { 'confesión' }\end{array}$ & $\begin{array}{l}\text { atorgamiento } \\
\text { de sus culpas }\end{array}$ & $\begin{array}{l}\text { es. otorgamiento } \\
\text { 'reconocimiento de } \\
\text { sus culpas' }\end{array}$ & $\mathrm{E}$ & 155: 12 \\
\hline viles & es. & bajas & es. 'baja' & $\mathrm{S}$ & 18: 27 \\
\hline vladica & $\begin{array}{c}\text { sr. y bl. vladika } \\
\text { 'príncipe- } \\
\text { obispo' }\end{array}$ & capo & it. 'líder', 'jefe' & $\mathrm{S}$ & 174: 11 \\
\hline voluntarios & es. & $\begin{array}{l}\text { guionulos / } \\
\text { guionullos }\end{array}$ & tr. gönüllü̈ & $\mathrm{S}$ & $\begin{array}{c}178: 23-4, \\
188: \\
19-20 \\
\text { y } 298: 7\end{array}$ \\
\hline yarišchí & $\begin{array}{l}\text { tr. yarışçı } \\
\text { 'competidor' }\end{array}$ & peleađor & es. & $\mathrm{S}$ & $82: 12$ \\
\hline yildiź & tr. $y ı l d ı z$ & estrella & es. & $\mathrm{S}$ & $28: 3$ \\
\hline źindán & $\begin{array}{l}\text { tr. zindan } \\
\text { 'calabozo' }\end{array}$ & $\begin{array}{c}\text { priśión } \\
\text { adientro la } \\
\text { tierra }\end{array}$ & es. & $\mathrm{E}$ & $155: 24$ \\
\hline
\end{tabular}

[Tabla 1: Glosas de sustantivos]

${ }^{32}$ Maestro o sabio en los asuntos religiosos islámicos. 


\subsection{Glosas de adjetivos}

\begin{tabular}{|c|c|c|c|c|c|}
\hline Forma Glosada & Procedencia & Glosa & Procedencia & Tipo & Loc. \\
\hline arbitrarias & es. & injustas & es. & $\mathrm{S}$ & 124: 6 \\
\hline concluiđos & es. & firmađos & es. & $\mathrm{S}$ & 94: 9 \\
\hline débiles & es. & flacos & es. & $\mathrm{S}$ & 268: 1 \\
\hline éxilađos & $\begin{array}{c}\text { cf. fr. exilé / es. } \\
\text { exiliado }\end{array}$ & surgún & tr. sürgün & $\mathrm{S}$ & 18: 12 \\
\hline fatídico & es. & de goral & $\begin{array}{l}\text { גורל es + hb. גורל } \\
\text { 'destino' }\end{array}$ & $\mathrm{S}$ & 1: 12 \\
\hline grave & es. & peśgađo & es. 'pesado' & $\mathrm{S}$ & $87: 16$ \\
\hline grosieras & $\begin{array}{l}c f . \text { fr. grossier / } \\
\text { es. grosero }\end{array}$ & cabáá & tr. $k a b a$ & $\mathrm{~S}$ & 47: 7 \\
\hline lamentable & es. & negro & es. & $\mathrm{S}$ & $\begin{array}{c}130: \\
23-24\end{array}$ \\
\hline mutilađa & es. & cortađa & es. & $\mathrm{S}$ & 163: 26 \\
\hline negro & es. & preto & pt. preto & $\mathrm{S}$ & 43: 27 \\
\hline no quiurazađo & $\begin{array}{c}\text { cf. fr. cuirasse } \\
+ \text { es. -ado / es. } \\
\text { acorazado }\end{array}$ & no źirḥlí & es. + tr. zırhll & $\mathrm{S}$ & 198: 3 \\
\hline quiurazađo(s) & $\begin{array}{l}c f . \text { fr. cuirasse } \\
+ \text { es. -ado / es. } \\
\text { acorazado }\end{array}$ & źirḥlí(s) & tr. zirhll & $\mathrm{S}$ & $\begin{array}{l}79: 14, \\
99: 6 y \\
199: 17\end{array}$ \\
\hline sufićientes & es. & bastantes & es. & $\mathrm{S}$ & $43: 24-25$ \\
\hline
\end{tabular}

[Tabla 2: Glosas de adjetivos] 


\subsection{Glosas de verbos}

\begin{tabular}{|c|c|c|c|c|c|}
\hline Forma Glosada & Procedencia & Glosa & Procedencia & Tipo & Loc. \\
\hline emigrando & es. & viniendo & es. & $\mathrm{E}$ & 270: 6 \\
\hline éxilađo & $\begin{array}{l}c f . \text { fr. exilé / es. } \\
\text { exiliado }\end{array}$ & surgún & tr. sürgün & $\mathrm{S}$ & $\begin{array}{c}57: 2 \\
149: 1 \mathrm{y} \\
306: 10\end{array}$ \\
\hline exilađos & $\begin{array}{l}c f . \text { fr. exilé / es. } \\
\text { exiliado }\end{array}$ & $\begin{array}{l}\text { mandađos } \\
\text { surgún }\end{array}$ & es. + tr. & $\mathrm{S}$ & $92: 2$ \\
\hline éxilar & $\begin{array}{l}c f . \text { fr. exiler / } \\
\text { es. exiliar }\end{array}$ & mandar surgún & es. + tr. & $\mathrm{S}$ & $67: 14$ \\
\hline explośando & $\begin{array}{l}c f . \text { fr. exploser } \\
\text { 'explotar' }\end{array}$ & parladeando & $\begin{array}{c}\text { tr. parlamak } \\
\text { 'inflamar' o } \\
\text { patlamak 'explotar' }\end{array}$ & $\mathrm{S}$ & 231: 13 \\
\hline explośar & fr. exploser & parladear & tr. & $\mathrm{S}$ & $75: 14$ \\
\hline iniciađo & es. & embeźađo & es. & $\mathrm{S}$ & $1: 18$ \\
\hline $\begin{array}{l}\text { (de) limitarsen al } \\
\text { rolo defensivo }\end{array}$ & $\begin{array}{l}\text { es. + cf. it. } \\
\text { ruolo / fr. rôle }\end{array}$ & de protejarsen & es. & $\mathrm{S}$ & 223: 20 \\
\hline referó & $\begin{array}{l}c f . \text { fr. référer / } \\
\text { es. referir }\end{array}$ & hiźo havalé & $\begin{array}{c}\text { es. + tr. havale } \\
\text { 'hacer transferencia' }\end{array}$ & $\mathrm{S}$ & 165: 6 \\
\hline se defendían & es. & se protejaban & es. & $\mathrm{S}$ & 223: 21 \\
\hline se necesita & es. & es menester & es. & $\mathrm{S}$ & $\begin{array}{c}130: \\
31-32 \\
\end{array}$ \\
\hline seducía & es. & candireaba & $\begin{array}{l}\text { cf. tr. kandırmak } \\
\text { 'seducir' }\end{array}$ & $\mathrm{S}$ & $59: 29-30$ \\
\hline
\end{tabular}

[Tabla 3: Glosas de verbos]

\subsection{Glosas de adverbios}

\begin{tabular}{|c|c|c|c|c|c|}
\hline Forma Glosada & Procedencia & Glosa & Procedencia & Tipo & Loc. \\
\hline abajo & es. & sud & cf. fr. / it. sud 'sur' & S & $186: 11$ \\
\hline ariba & es. & nord & $\begin{array}{c}c f \text {. fr. / it. } \text { nord } \\
\text { 'norte' }\end{array}$ & S & $\begin{array}{c}183: 23 \mathrm{y} \\
186: 9\end{array}$ \\
\hline definitivamente & es. & no por horas & es. & E & $89: 2$ \\
\hline iEvet! ;Evet! & tr. evet & iSí! iSí! & es. & S & $\begin{array}{c}125: 18 \mathrm{y} \\
127: 10\end{array}$ \\
\hline
\end{tabular}

[Tabla 4: Glosas de adverbios] 


\subsection{Glosas de frases completas}

\begin{tabular}{|c|c|c|c|c|c|}
\hline Forma Glosada & Procedencia & Glosa & Procedencia & Tipo & Pág.: lín. \\
\hline $\begin{array}{l}\text { ¿Bašindán_mi } \\
\text { corquiorsún? }\end{array}$ & $\begin{array}{l}\text { tr. Başından mı } \\
\text { korkuyorsun? }\end{array}$ & $\begin{array}{c}\text { ¿Te espantas por } \\
\text { tu vida? }\end{array}$ & es. & $\mathrm{S}$ & $317: 12$ \\
\hline $\begin{array}{c}\text { Guioźum } \\
\text { guiormesin. }\end{array}$ & $\begin{array}{l}\text { tr. Gözüm } \\
\text { görmesin. }\end{array}$ & $\begin{array}{c}\text { Que mis ojos no lo } \\
\text { vean más }\end{array}$ & es. & $\mathrm{S}$ & $38: 9$ \\
\hline ¿Ne yapmalí? & tr. Ne yapmall? & ¿Cuálo haćer? & es. & $\mathrm{S}$ & $320: 24$ \\
\hline ¿Quiem-dir o? & tr. Kimdir $o ?$ & ¿Quén es? & es. & $\mathrm{S}$ & 197: 6 \\
\hline ¡Sen suś! & tr. Sen sus! & ¡Tú estate callađo! & es. & $\mathrm{S}$ & 125: 22 \\
\hline $\begin{array}{l}\text { ¡Vah! ¿Bu hala_ } \\
\text { mi guieldím? }\end{array}$ & $\begin{array}{l}\text { tr. Vah! Bu hale } \\
\text { mi geldim? }\end{array}$ & $\begin{array}{l}\text { ¡Ah! ¿A este } \\
\text { estađo cayí }{ }^{33}\end{array}$ & es. & $\mathrm{S}$ & $157: 7-8$ \\
\hline Vur muhurú & tr. Vur mühürü. & Chaptea $^{34}$ el sello & tr. + es. & $\mathrm{S}$ & $38: 16-17$ \\
\hline ¡Yabanĝ́i deguil! & $\begin{array}{l}\text { tr. Yabancı } \\
\text { değil!! }\end{array}$ & ¡No es ajeno! & es. & $\mathrm{S}$ & 197: 5 \\
\hline $\begin{array}{c}\text { Yuź verileĝek } \\
\text { mahluc } \\
\text { deguieldir. }\end{array}$ & $\begin{array}{c}\text { tr. Yüz } \\
\text { verilecek } \\
\text { mahluk } \\
\text { değildir }{ }^{35} \text {. }\end{array}$ & $\begin{array}{c}\text { No es pasta de } \\
\text { darle cara }\end{array}$ & es. & $\mathrm{S}$ & 21: 29 \\
\hline
\end{tabular}

[Tabla 5: Glosas de frases completas]

${ }^{33} \mathrm{El}$ término aparece sin álef en el texto original, lo que no es un caso común, así que muy probablemente es una errata de imprenta.

${ }^{34}$ Según el diccionario de J. Nehama (Dictionnaire du Judéo-Espagnol [Madrid 1977] s.v. čakteár) el término viene del verbo çaktırmak, aunque creemos que viene del verbo turco çakmak 'clavar, pegar', cuyo significado coloquial se aproximaría más en este caso; çak mühürü̈!, por ejemplo, es una expresión relativamente común en turco, que podría traducirse como '¡estampa el sello!'.

${ }^{35}$ Yüz verilecek mahluk değildir. Es una expresión turca y en la forma glosada nos encontramos con una traducción literal de la misma, que se podría traducir de la siguiente manera: «No tiene pasta para que le hagas caso». Lo que quiere decir es que es muy malo, que ni se merece ser mimado o apreciado». 


\section{ORIGEN DE LAS GLOSAS}

Resulta difícil establecer el origen de los préstamos románicos dada su etimología común, teniendo en cuenta además que muchos son objeto de cambios morfológicos dependiendo de cómo y dónde se transmitan, y quién los divulgue. De acuerdo con lo señalado por García Moreno, en nuestro caso también la mayor dificultad ha sido

[...] determinar si se trata de préstamos del francés adaptados a la fonética judeoespañola, pues formalmente vienen a coincidir con los paralelos del español estándar. El problema no se limita con el francés o español sino se amplia hacia los otros idiomas románicos, incluso el turco ${ }^{36}$.

Una palabra de origen francés, también podría encontrarse en italiano, portugués o español estándar del tiempo, incluso también en turco, lengua que también tiene muchos préstamos de dichos idiomas, especialmente del francés. Por otro lado, aunque a veces la fonética de estos préstamos nos da indicios de su origen, no es fácil precisarlo con exactitud y certeza. Por ejemplo, el término rolo 'papel' podría haber sido tomado del francés rôle o del italiano ruolo o tal vez del turco rol, que ya lo había adoptado del francés. Si se considera el período en que se publica la obra de Gaḅay, la mezcolanza de lenguas y por tanto la ambigüedad en cuanto a la etimología pueden fácilmente confundirnos.

Pese a todo, a continuación presentamos un gráfico donde se listan las procedencias tanto de las formas glosadas como de las glosas ${ }^{37}$.

${ }^{36}$ Vid. García Moreno, «Glosas frescas en La hermośa Hulda de España (Jerusalén, 1910)», pág. 80.

${ }^{37}$ Cabe destacar que en los gráficos siguientes, el turco (tr.) y las palabras anticuadas en desuso en el turco actual (tr. ant.) no se distinguen como sí hacíamos en las tablas anteriores. Cada columna representa la procedencia del término según el orden señalado en la parte superior del gráfico. En cuanto a las procedencias dudosas, para este gráfico se tiene en cuenta la primera posibilidad de las que aparecen en las tablas anteriores. 


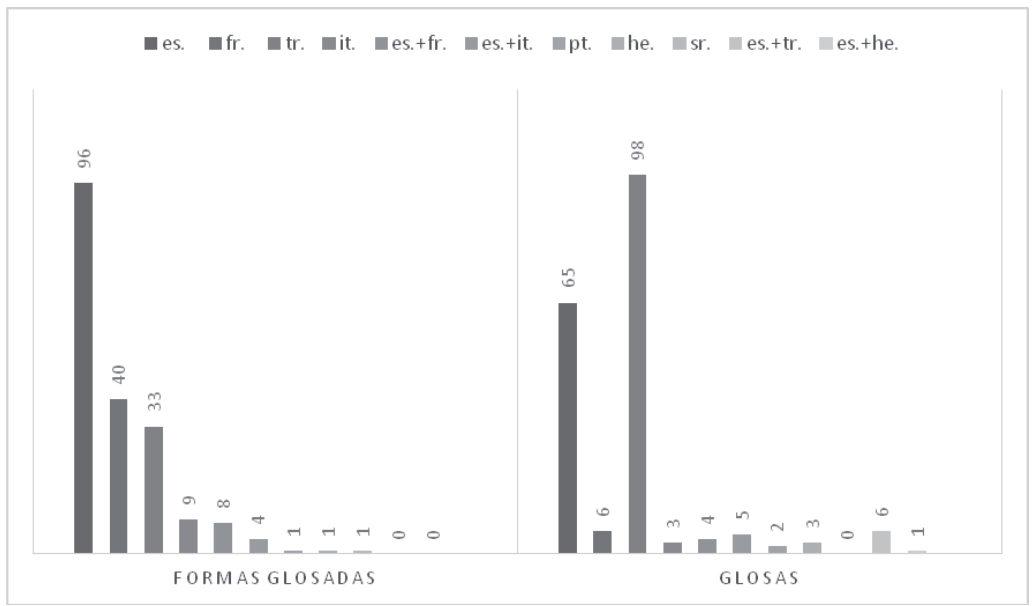

[Gráfico 2: Número de las formas glosadas y glosas según su procedencia]

Tras analizar las formas glosadas y las glosas sólo en función de su procedencia sin relacionarlas entre sí, nos parece oportuno analizar la lengua de origen de las formas incluidas en las glosas (columnas), en relación con el origen de las formas glosadas:

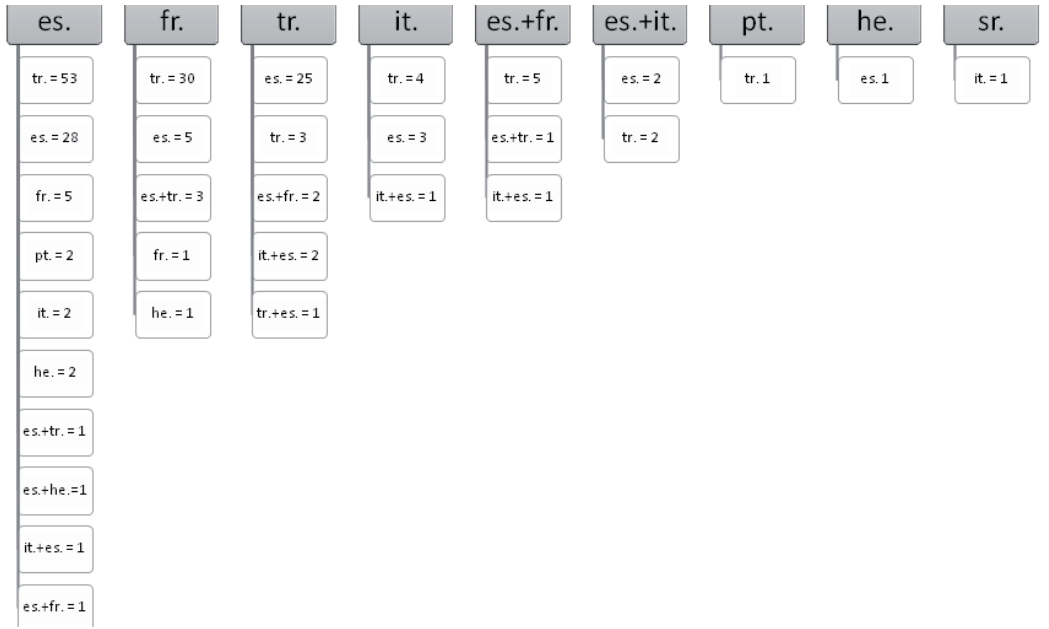

[Gráfico 3: Fondo léxico de las glosas en relación a la procedencia de la forma glosada] 
Siguiendo los datos expuestos arriba y centrándonos en la procedencia más frecuente de las glosas, podemos señalar que Gaḅay recurre para glosar aproximadamente en un 50\% a términos turcos de los cuales la mayoría sirve para aclarar un hispanismo, galicismo o italianismo, y cabe preguntarse a qué campo semántico corresponden las glosas realizadas con turquismos. Como se puede comprobar en los cuadros anteriores tienen rasgos comunes de significantes que se podrían calificar como 'tecnicismos'; es decir, la mayoría de los rasgos significantes están relacionados con los términos otomanos del momento (política, instituciones, guerra, etc.). Por ejemplo, es muy frecuente el campo semántico militar, así frontera (hudud) [tr. hudut < ár. hudūd]]; fuśil(es) (tufenc) [tr. tüfek < fa. tufeng]; bayoneta (sungyú) [tr. süngü], etc. Lógicamente, el de los cargos militares y políticos o el de las instituciones: almirantia (tersané) [tr. tersane], capitán (yuź bašî́) [tr. yüzbaşı ], cámara (mebusán meĝlisî) [tr. ant. mebusan meclisi], consejero de estado (en el šurayi-dovlet) [tr. ant. şûrrayı devlet], etc.

Dado que más del 50\% de las formas glosadas son términos de origen hispánico hemos de deducir que estos no serían del todo bien conocidos por los lectores y por ello el autor se ve en la necesidad de glosarlos. Se observa que entre estos términos o expresiones glosados hay a veces combinaciones de un hispanismo con un galicismo o italianismo y la glosa suele corresponder a un turquismo, por ejemplo: consilio de estado (šurayi-dovlét) [tr. ant. şûrayı devlet], consilio de_los ministros (yuquiela-meghlisi) [tr. ant. meclisi vükela]; a nuestro modo de ver, esto refleja que los hispanismos, galicismos e italianismos están presentes en la lengua judeoespañola pero necesitan alguna aclaración, o bien el autor quiere que estén presentes al lado del término institucional turco.

El recurso al turco para clarificar ese campo semántico es explicable por la temática de la obra en sí y resulta justificable que los sefardíes no conocieran los términos en español contemporáneo.

Por su parte, merece la pena subrayar que los turquismos glosados parecen de nueva incorporación al judeoespañol y son, en algún caso, tecnicismos también: la mayoría están explicados mediante un hispanismo, y alguno en combinación con un italianismo o un galicismo. Por otro lado los portuguesismos y aun algún italianismo que encontramos en el texto son antiguos en judeoespañol por lo que su origen último no resulta relevante ya. También hay que resaltar que dentro de los neo- 
romanismos presentes en las formas glosadas es abrumadoramente mayoritaria la presencia de galicismos frente a, por ejemplo, los italianismos que pueden documentarse en obras sefardíes del momento de áreas geográficas como Salónica o los germanismos de los textos vieneses o del noroeste balcánico ${ }^{38}$.

Por otro lado, es reseñable que tanto en las formas glosadas como en las glosas aparecen muy pocos hebraísmos, si bien tampoco es algo demasiado extraño, dado el bajísimo número de formas del fondo hebreo presentes en la obra. Además, entendemos que las voces hebreas documentadas en el texto -estando en su mayoría relacionadas con el mundo cultural-religioso tradicional de los sefardíes- serían perfectamente conocidos por los lectores como para no necesitar ser glosadas.

\section{EL USO DE LAS GLOSAS}

Una carencia de la sistematización en el empleo de las glosas léxicas está presente a lo largo de todo nuestro corpus. El recurso de la glosa por parte de Gabay es tan caprichoso que no hemos podido definir ninguna sistematización para su uso. Por supuesto, las glosas se utilizan para ayudar a la comprensión del texto, pero hay casos en los que nos surge la duda, casos en los que una palabra se utiliza sin glosa y la misma palabra aparece con glosa en las páginas siguientes. Esto se podría explicar por la forma de difusión de la obra ya que ésta se publicaba por entregas, probablemente en el periódico del autor El Telégrafo. A continuación, vemos algunos ejemplos de este uso:

${ }^{38}$ Véanse los apartados dedicados a Extranjerismo en A. GARCíA Moreno, «Variedad de variedades: diferencias léxicas en dos versiones judeoespañolas (Viena, 1877 y Salónica, 1891) de la novela alemana Der Rabbi und der Minister», en Actas del VIII Congreso Internacional de la Asociación de Historia de la Lengua Española, ed. E. Montero Cartelle (Santiago de Compostela 2012) págs. 1369-1383: 1379-1380, y «Río abajo, tiempo después: diferencias léxicas en dos versiones sefardíes danubianas (Viena 1877 y Belgrado 1906) de la novela alemana Der Rabbi und der Minister», en Sefarad an der Donau. Lengua y literatura de los sefardies en tierras de los Habsburgo, eds. M. Studemund-Halevy, Ch. Liebl e I. Vučina (Barcelona 2013) págs. 203-219: 215216, así como su libro, Der Rabbi und der Minister: dos versiones judeoespañolas de la novela alemana. Edición y estudio filológico (= Colección Fuente Clara. Estudios de cultura sefardí 24 [Barcelona 2013]) §4.3.4, págs. 51-53. 
$\mathrm{Al}$ recurrir a la explicación entre paréntesis la tendencia del autor es aclarar el término la primera vez que aparece y luego no repetirlo más.

Hay veces en que el autor recurre a la glosa entre paréntesis para explicar una palabra y repite la glosa casi siempre que aparece aquella, como ocurre con la palabra önиque(s) que siempre se acompaña de la glosa hadum(es) -salvo en la pág. 77 en que el término aparece dos veces pero solo se introduce la glosa en la primera ocurrencia- ${ }^{39}$. Otro ejemplo lo encontramos en la glosa hudud que es la traducción del italianismo frontiera $^{40}$. A diferencia del ejemplo anterior, la forma glosada aparece sola, es decir, sin aclaración parentética, en no pocas ocasiones ${ }^{41}$.

Otras veces, aunque en su primera ocurrencia una palabra no esté explicada, sí aparece con glosa en las siguientes. Así, el término plática aparece ocho veces en el texto junto con su forma verbal platicar (págs. 43, 51, 131, 134-136, 138 y 140); sin embargo, no aparece como aclaración de la forma discusión, entre paréntesis, hasta la séptima vez que se emplea, concretamente en la página 138.

Otro caso similar es el de poner la glosa entre paréntesis la primera vez que emplea ese término, pero después pasar a utilizar el vocablo que aparecía en la glosa; tal es el caso de bullor, que la primera vez que aparece (pág. 258) sirve de aclaración al término efervecencia, y luego pasa a utilizarse en solitario (pág. 282).

Por otro lado, encontramos algunas voces aclaradas con diferentes palabras en distintas ocasiones. Por ejemplo, para aclarar el término turco antiguo šurayi dovlet 'consejo de estado' usa dos diferentes formas glosadas: consejero de estado en la página 4; consello de estado en la página 157.

\subsection{El uso de las glosas, ¿muestra de occidentalización de la lengua?}

Tras analizar las glosas léxicas usadas por Gaḅay, la primera pregunta que se nos presenta es el porqué del uso de estas glosas. Si los receptores de la obra entienden el término glosado ¿por qué el autor tuvo que pun-

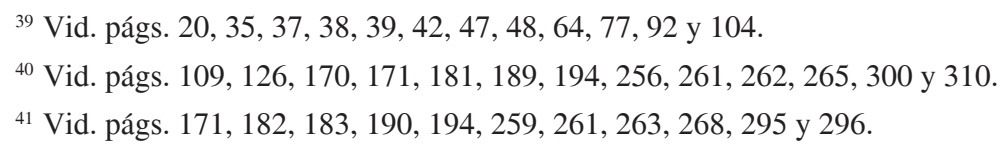


tualizar su significado? ¿O no lo entendían, o al menos no todos? ¿Querría Gabay mostrar la riqueza de su propio conocimiento de otras lenguas, o querría occidentalizar y modernizar un judeoespañol que pudiera entenderse demasiado turquizado?

Es cierto que la función principal de las glosas es hacer alguna aclaración a ciertos términos, o sea, facilitar la comprensión del texto; sin embargo, lo más fácil habría sido dejar los términos más comprensibles para el receptor en vez de sustituirlos por otros, como hemos visto, en su mayoría, románicos. ¿O acaso Gabay emprendió el labor de modernizar la lengua de sus lectores a través de su periódico y de ahí el recurso a las glosas léxicas?

La respuesta a esta última pregunta parece claramente afirmativa si tenemos en cuenta tanto la opinión de otros investigadores, como las informaciones que nos brindan intelectuales contemporáneos a Gaḅay.

Así, tal y como señala Schmid,

La prensa tuvo un papel primordial en la modernización de la lengua y los periodistas en muchos casos eran perfectamente conscientes de ello, hasta tal punto que a menudo se nota el afán didáctico de enseñar a los lectores el léxico moderno. A este respecto son de mucho interés las glosas explicativas que frecuentemente acompañan a los neologismos ${ }^{42}$.

Esta opinión se apoya, entre otras cosas, en lo apuntado en su día por el rabino Abraham Cappon (1853-1931) al hablar acerca de la lengua judeoespañola usada en su revista, cuando recomendaba a sus lectores que con un poco de entrenamiento se acostumbrarían a un lenguaje más científico, y ponía como ejemplo precisamente a los meldadores de los periódicos sefardíes de Estambul, incluido El Telégrafo del propio Gabay, del que destacaba su estilo «científico-literario»:

Nośotros conocemos muchos israelitas de Constantinopla y de otras civdades de la Turquía que, sin haver embeźado en la escola, entienden muy bien el consideravle jurnal «El Tiempo»y otros como es el «Telegrafo» etcetera, los cuales emplean el estilo científico-literario, serviendo de escola a una grande cuenta de sus lectores ${ }^{43}$.

${ }^{42}$ Vid. Schmid, «La lengua sefardí en su plenitud», pág. 69.

${ }^{43}$ Apud Schmid, «"Por el adelantamiento de la nación”», págs. 105-106. 
Según Cappon, el lenguaje de su revista debía ser tanto popular y entretenido como literario y científico, con la introducción de neologismos, y explicaba lo que el escritor debía hacer ante esta aparente contradicción:

El deber de los escritores es señalar en parenteśes (...) el entendimiento de los biervos que pueden ser reemplazados con la lingua uśada, o mijor digamos: con palavras rumenas, turcas o búlgaras, donde nuestro castellano está guarnecido (mezclado), ma él es todavía forzado de seguiir su linguaje, sin traducir lo que no se puede y que en queriendo haćerlo el estilo pierde su justa siñificación ${ }^{44}$.

La mayoría de estas nuevas incorporaciones procede de lenguas occidentales y en particular del español estándar de la época, exactamente como declaraba M. L. Wagner cuando afirmaba que «tiene ocasión de tratar en Oriente a varios sefardíes cultos, los cuales condenaban el empleo excesivo de palabras exóticas y propendían al purismo».

Wagner también señalaba que «hay periodistas sefardíes que, en sus artículos, tratan de evitar los términos turcos y de expresarse en puro español», señalando a continuación: «lo cual les obliga a menudo a añadir entre paréntesis la palabra turca usual, para hacerse comprender por sus lectores, y no les impide el tomar a veces por españolas de buena ley expresiones de indudable origen gálico» ${ }^{45}$.

Esta misma opinión la vemos en la obra del Senador Ángel Pulido Los israelitas españoles y el idioma castellano, donde encontramos una carta enviada al Senador por Mois dal Medico, «coronel, primer secretario interprete del Ministerio de la Marina Imperial otomana en Constantinopla» y cuñado de Iśac Gaḅay, y que fue redactor del periódico El Telégrafo. Sus opiniones acerca de la situación del judeoespañol del momento nos dan una idea de las tendencias de los periodistas estambulíes. Veamos un fragmento de la carta de Dal Medico dirigida al Senador, con fecha 27 de Febrero de 1904 y firmada en Estambul ${ }^{46}$ :

${ }^{44}$ Apud Schmid, «"Por el adelantamiento de la nación”», págs. 105-106.

${ }^{45}$ M. L. WAGner, «Algunas observaciones generales sobre el judeo-español de Oriente», Revista de Filología Española 10 (1923) págs. 225-244: 227.

46 Á. Pulido, Los israelitas españoles: el idioma castellano (Madrid 1904) págs. 175176. Las cursivas son del original. 
[...]1. Estado actual de la lengua español en Oriente.-Muy escaso es el numero de judios en Oriente que estudian la lengua español. Ellos la aprenden prácticamente; a penas ay algunos que procuran a hablarla y escribirla mas o menos correctamente, merced a las obras españolas que leen y al empleo del diccionario, muy ralamente de la gramatica.

Ay pues dos categorías de judíos que hablan el castellano: los inorantes y los instruidos. Los primeros hablan y escriben el español del siglo dé Fernando y Isabela, corrumpido y mesclado de un gran numero de voces hebreas, turcas y slavas (en Serbia y Bulgaria).

Ay también ciertas diferencias entre los idiomas de los diferentes países y provincias. En Salonico por ejemplo emplean ainda facer, fijo, mientras que en las otras partes hacer, hijo; en Salonico dicen ciuda, bonda, en los otros lugares civdad, buendad. Endesparte de esto ellos emplean ciertas voces de las que la etimología seria difícil a hallar. Tales son: meldad (leer), jara (bosque), reda (pañuelo), avíamela (prima), péndola (pluma) etc. etc.

Los instruidos, quero decir los que conocen las lenguas europeas y particularmente los redactores de diarios judeo españoles, los traductores de romanzos y otros libros, evitan el empleo de voces estrangeras y procuran á no hacer uso mas que de palabras puramente españolas, pero cometen sin apercibirsen dos grandes faltas: dan a las voces españolas la pronuncion francesa y la construcción y el estilo lejos de ser español es mas bien francés o italeano.

No dudo que yo también me hallo en el mesmo caso que estos últimos. $[\ldots]$

De acuerdo con todo esto, y siguiendo lo señalado más arriba sobre las ideas lingüístico-literarias de Cappon, deducimos que Gaḅay intenta en textos como Yildiź y sus secretos utilizar un lenguaje más modernizado; sin embargo, al igual que Cappon, no puede dejar su protagonismo didáctico y, a la vez que introduce neologismos, sigue recurriendo al término más popular y común entre sus lectores.

Teniendo en cuenta que, según nuestro análisis, la mayoría de las explicaciones parentéticas de léxico están hechas mediante turquismos, entendemos que Gaḅay tenía la intención de introducir nuevos términos cuyos equivalentes ya existían en la lengua sefardí con formas de origen turco, para pulir el judeoespañol de turquismos, reconduciendo a su lector hacia las formas hispánicas ya existentes en judeoespañol, o al menos proveyéndolo con su equivalente en otras lenguas románicas 
prestigiosas para los sefardíes, y así re-castellanizar o modernizar el judeoespañol.

Asimismo, como señala Dal Medico en su carta, aunque la mayoría de los neologismos introducidos proceden del español, el autor no puede evitar usar galicismos por razones perfectamente comprensibles, y así señala Schmid:

La modernización general de los habitantes de la zona tras la apertura del Imperio Otomano hacia Occidente, las nuevas realidades tanto sociales y culturales como técnicas, etcétera, habían hecho necesarias la ampliación y la modernización del vocabulario. Puesto que las novedades llegaban a los sefardíes mayormente desde Francia, no sorprende que se introdujeron al mismo tiempo los términos franceses correspondientes ${ }^{47}$.

En resumen, el deseo de utilizar neologismos podría explicarse por la intención de los autores, traductores y periodistas sefardíes de modernizar la lengua de sus correligionarios a través de la lengua empleada en sus escritos. Pero sin olvidar, como escriben Hernández Socas et al. tras analizar otros especialistas, que

[...] puede resultar difícil diferenciar entre el uso de glosas (a) para introducir términos con el fin de modernizar u occidentalizar la lengua, (b) con el afán de nivelar los conocimientos al utilizar terminología especializada, que, en el caso del judeoespañol, también procede de las lenguas de contacto occidentales, y (c) el deseo de efectuar una ampliación y distinción diafásica ${ }^{48}$.

En nuestro texto, Gabay recurre a las glosas para aclarar tanto neologismos, como formas patrimoniales ${ }^{49}$-que, a su vez, podían ser de origen hispánico o tomadas de otras lenguas en el pasado-, con la intención de modernizar sensu lato el judeoespañol. De hecho, podemos decir que muchos de los extranjerismos glosados en Yildiź y sus secretos habían sufrido un proceso de patrimonialización dentro de la lengua sefardí, en tanto que otras palabras procedentes de len-

${ }^{47}$ Vid. Schmid, «La lengua sefardí en su plenitud», pág. 68.

${ }^{48}$ Vid. Hernández Socas et al., «La función de las glosas en el El Trajumán de Michael Papo (1884)», pág. 405.

${ }^{49}$ Agradecemos al Dr. García Moreno sus indicaciones en relación con las familias léxicas patrimoniales. 
guas extranjeras -incluido el turco- eran de nueva incorporación en el momento en que Gabay redacta su texto. Por ejemplo, los turquismos glosados por Gaḅay constituyen neologismos en judeoespañol a la vez que son extranjerismos; en tanto que el hecho de que Gabay utilice palabras de origen turco tanto en las glosas como en los términos glosados parece indicar que los potenciales lectores conocían dicha lengua en un grado aceptable ${ }^{50}$.

\section{Conclusión}

Aun conscientes de la imposibilidad de ofrecer una afirmación definitiva acerca del uso de las glosas en los textos sefardíes al basarnos en el análisis de una única obra, podríamos destacar que se pueden obtener muchos datos sobre el léxico del libro examinado consultando las glosas incorporadas a lo largo del texto. Como hemos venido indicando, los datos que ofrece la obra de Gabay son muy valiosos, pues nos muestran el alto grado de relación que, en esos momentos, el judeoespañol tenía con otras lenguas y cómo algunas de ellas eran consideradas modernas y, por tanto, prestigiosas en el ambiente cultural sefardí, hasta el punto de que los escritores tomaran prestadas voces de su léxico que consideraban oportuno incorporar a su lengua, en detrimento de palabras patrimoniales o préstamos lingüísticos más antiguos.

A la vez, es apreciable el relativo conocimiento que del turco debían de tener los sefardíes de Estambul, pues el autor tiene una gran tendencia a usar en sus glosas voces de origen turco y, lo que parece más importante a nuestro modo de ver, glosar sólo treinta y tres voces de origen turco, en un texto donde aparecen muchos más turquismos, nos hace pensar que estos eran entendidos fácilmente por el lector y la lectura del texto les era cómoda.

Según nuestra opinión, queda clara la intención del autor por enriquecer el vocabulario del judeoespañol integrando nuevas voces a su idioma,

\footnotetext{
${ }^{50}$ Aunque es imposible afirmar categóricamente que los sefardíes hablaran turco, su integración social, prácticamente en todos los campos, hace difícil imaginar que no se pudieran comunicar con sus conciudadanos no-sefardíes, y probablemente, sólo algunos sectores de la comunidad sefardí mantendrían un aislamiento lingüístico total más allá del círculo comunitario.
} 
en particular del español y francés, pero también con nuevos turquismos no patrimonializados.

El uso de las glosas para ofrecer un sinónimo de una palabra de origen español con otra palabra también en español nos da muestra de la riqueza del léxico del autor, ya que es un signo de contacto con el castellano del momento y, al tiempo que trata de modernizar su lengua, utilizando nuevos vocablos, aporta su sinónimo para aquel lector que seguramente desconociera el español moderno.

Al mismo tiempo nos aporta importante información sobre la terminología empleada en el judeoespañol más antiguo, lo que permite distinguir los diferentes estadios, siendo de gran utilidad tanto a los investigadores de la lengua sefardí como a los historiadores de la lengua española.

Recibido: $12 / 05 / 2016$

Aceptado: 13/07/2016 